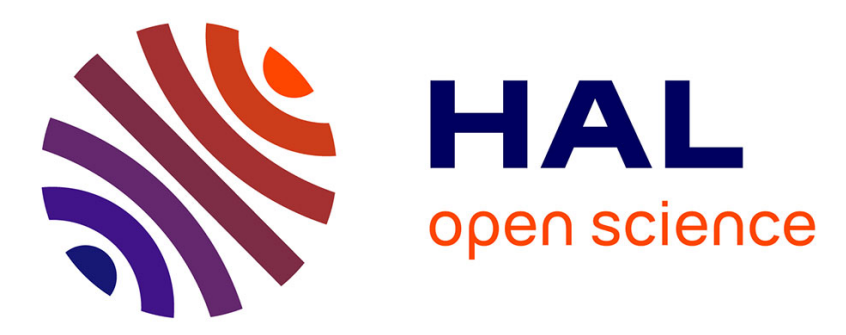

\title{
Lawsonite metasomatism and trace element recycling in subduction zones
}

\author{
A. Vitale Brovarone, Olivier Alard, O. Beyssac, L. Martin, M. Picatto
}

\section{To cite this version:}

A. Vitale Brovarone, Olivier Alard, O. Beyssac, L. Martin, M. Picatto. Lawsonite metasomatism and trace element recycling in subduction zones. Journal of Metamorphic Geology, 2014, 32 (5), pp.489-514. 10.1111/jmg.12074 . hal-01107395

\section{HAL Id: hal-01107395 \\ https://hal.science/hal-01107395}

Submitted on 6 Dec 2018

HAL is a multi-disciplinary open access archive for the deposit and dissemination of scientific research documents, whether they are published or not. The documents may come from teaching and research institutions in France or abroad, or from public or private research centers.
L'archive ouverte pluridisciplinaire HAL, est destinée au dépôt et à la diffusion de documents scientifiques de niveau recherche, publiés ou non, émanant des établissements d'enseignement et de recherche français ou étrangers, des laboratoires publics ou privés. 


\title{
Lawsonite metasomatism and trace element recycling in subduction zones
}

\author{
A. VITALE BROVARONE, ${ }^{1}$ O. ALARD, ${ }^{2}$ O. BEYSSAC, ${ }^{1}$ L. MARTIN ${ }^{3}$ AND M. PICATTO ${ }^{4}$ \\ ${ }^{7}$ Institut de Minéralogie, de Physique des Matériaux, et de Cosmochimie (IMPMC), Sorbonne Universités - UPMC Univ \\ Paris 06, UMR CNRS 7590, Muséum National d'Histoire Naturelle, IRD UMR 206, 4 Place Jussieu, F-75005 Paris, France \\ (alberto.vitale-brovarone@impmc.upmc.fr) \\ ${ }^{2}$ Géosciences Montpellier, Université Montpellier II, place E. Bataillon, 34095, Montpellier, France \\ ${ }^{3}$ Centre for Microscopy, Characterisation and Analysis, University of Western Australia, Crawley, WA, 6009, Australia \\ ${ }^{4}$ Dipartimento di Scienze della Terra, Università degli Studi di Torino, via Valperga Caluso 35, 10100, Torino, Italy
}

\begin{abstract}
Although lawsonite-bearing rocks are rare in exhumed high-pressure (HP) terranes, they are considered to exert a primary role in subduction dynamics. Recent observations in natural settings have shown that fluid-rock interaction at HP conditions, including metasomatism, may lead to unusually high lawsonite amounts even in rocks that originally contained little or no lawsonite. This process may therefore bear important implications for element recycling in subduction zones. A detailed characterization of the geochemical fingerprints associated with lawsonite metasomatism is presented in this contribution. The studied rocks belong to the HP terranes of Alpine Corsica (France), which is the largest documented exposure for lawsonite metasomatism. Metasomatic lawsonite displays complex compositional zoning, including high trace element, $\mathrm{Cr}$ and $\mathrm{Ti}$ content. The trace element content is much higher compared with the average of non-metasomatic lawsonite, and is in line with the re-incorporation of large amounts of trace elements (e.g. REE, $\mathrm{Sr}, \mathrm{Pb}, \mathrm{Th}$ ) in the rock during metasomatism, as shown by mass transfer calculations. Our data suggest that serpentinites represented the main fluid source for the metasomatism, with concurrent contribution of other, possibly Ca-rich lithologies, such as mafic or meta-sedimentary rocks. We propose that the breakdown of metasomatic lawsonite may contribute to the genesis of magmas and their characteristic geochemical signatures.
\end{abstract}

Key words: HP fluid-rock interaction; lawsonite; lawsonite-eclogite; lawsonite metasomatism; trace element recycling.

\section{INTRODUCTION}

In subduction zones, crustal material may return into the Earth's interior, with important implications for global element recycling. Petrological and geochemical processes at plate boundaries play a fundamental role in the selective return of elements to the lithosphere or atmosphere in volcanic arcs, or their sink into the mantle (e.g. Kerrick \& Connolly, 2001; Hacker, 2008). Combining volcanology, experimental petrology and geochemical studies on synthetic and exhumed natural samples, these processes can be assessed by tracing the evolution of specific geochemical tracers during high-pressure (HP) metamorphism, most notably volatiles and trace elements.

The hydrous phase lawsonite $\left[\mathrm{CaAl}_{2}\right.$ $\left.\mathrm{Si}_{2} \mathrm{O}_{7}(\mathrm{OH})_{2} \cdot \mathrm{H}_{2} \mathrm{O}\right]$ has a scientific interest beyond the limits of petrology/mineralogy as it may be responsible for the transfer of large amounts of water into the mantle, and its breakdown may have far-reaching consequences for magma genesis and seismogenesis at plate boundaries (e.g. Poli \& Schmidt, 1997; Hacker, 2008; Abers et al., 2013). Together with the large amount of water, up to $\sim 11-12 \mathrm{wt} \% \mathrm{H}_{2} \mathrm{O}$, lawsonite can accommodate very high concentrations of trace elements such as rare earth elements (REE), $\mathrm{Sr}, \mathrm{Pb}$, $\mathrm{Th}$ and $\mathrm{U}$ in its formula (Spandler et al., 2003; Martin et al., 2014). Moreover, its stability, down to $300 \mathrm{~km}$, exceeds that of other hydrous phases such as antigorite and chlorite (Poli \& Schmidt, 1997; Okamoto \& Maruyama, 1999). The combination of a large amount of water, high trace element concentration and stability at great depths make lawsonite-bearing rocks an exceptional natural tool for understanding the process of element recycling in subduction zones.

Lawsonite has been shown to be present in a number of high-pressure/low-temperature (HP/LT) metamorphic belts, and is predicted to be stable in thermal models of subduction zones (e.g. Peacock, 1999; Tsujimori et al., 2006a; van Keken et al., 2011; Abers et al., 2013; Tsujimori \& Ernst, 2014). However, lawsonite in mountain belts is rare, including in eclogite facies terranes (e.g. Clarke et al., 2006; Tsujimori et al., 2006b; Whitney \& Davis, 2006). The occurrence or non-occurrence of lawsonite in exhumed HP rocks of cold and intermediate subduction zones may depend on either insufficient water content (e.g. Clarke et al., 2006), or be a consequence 
of its overprint at lower $P-T$ conditions during decompression (e.g. Whitney \& Davis, 2006; Vitale Brovarone et al., 2011a). In favourable lithologies, e.g. altered basalts/gabbros, lawsonite may represent a major phase, and plays an important role for the redistribution of trace elements at $\mathrm{HP}$ (Spandler et al., 2003). On the contrary, in $\mathrm{Ca}, \mathrm{Al}$ or $\mathrm{H}_{2} \mathrm{O}$-poor rocks (e.g. metapelite s.s., gneissic rocks), its amount is negligible, thus implying repartition of trace elements in other phases, e.g. garnet, epidote-group minerals.

It has been demonstrated that HP metasomatism may result in voluminous precipitation of lawsonite (Tsujimori et al., 2006b; Martin et al., 2011a; Vitale Brovarone et al., 2011b). Part of these processes happens during the exhumation of HP rocks (e.g. Franciscan rocks, Krogh et al., 1994) or during the peak stage (e.g. Martin et al., 2011a). However, relevant geological implications have been poorly deciphered owing to the scarcity of the samples described so far. In this contribution, we present structural, petrological and geochemical data of several occurrences of blueschist and eclogite facies lawsonite-bearing metasomatic rocks, such as lawsonitite (lawsonite $>75$ vol.\%), from Alpine Corsica. Alpine Corsica is a type locality for lawsonite and lawsonite-eclogite (Caron \& Péquignot, 1986; Tsujimori et al., 2006a; Ravna et al., 2010; Vitale Brovarone et al., 2011a), and hosts the largest exposure of lawsonite metasomatites so far documented, as shown in this paper. This process is able to modify the composition of rocks unsuitable for lawsonite formation into lawsonite-rich rocks, and it allows the incorporation of large amount of trace elements circulating at HP. After a general overview of lawsonite metasomatites, this paper focuses on the geochemical patterns associated with lawsonite metasomatism, and its possible fluid and elemental sources. We show that these rocks offer a powerful mean to investigate the origin, behaviour and composition of fluids and trace element mobility at HP.

\section{GEOLOGICAL SETTING}

Alpine Corsica (France) represents a segment of the Alpine orogenic system now isolated from the European mainland by the opening of two back-arc-type basins, namely the Ligurian-Provençal basin and the Tyrrhenian basin (Fig. 1a) (e.g. Jolivet et al., 1990; Speranza et al., 2002; Molli \& Malavieille, 2010; Vitale Brovarone et al., 2013). Alpine Corsica occupies the northeastern part of the island of Corsica and can be subdivided into three main domains (see recent review by Vitale Brovarone et al., 2013 and references therein): (i) the Corsica continental margin units, which experienced low-grade blueschist metamorphism; (ii) the Schistes Lustrés complex, consisting of remnants of Tethyan oceanic lithosphere metamorphosed under HP-LT conditions; and (iii) the so-called Nappes Supérieures, which include subgreenschist facies ophiolitic and continental units.

This study focuses on two units of the Schistes Lustrés complex, namely the Lawsonite-blueschist and Lawsonite-eclogite units. Both units consist of segments of Tethyan lithosphere and include metaophiolites, i.e. serpentinites, metabasalts and metagabbro, meta-sedimentary rocks and local continental basement slivers lying on serpentinite and interpreted as rift-related continental extensional allochthons (e.g. Vitale Brovarone et al., 2011b; Meresse et al., 2012). Lawsonite is generally well preserved in both units, but local intense retrogression occurred in the epidote stability field.

The Lawsonite-blueschist unit consists of dominant meta-sedimentary rocks and subordinate slices of mafic/serpentinite ophiolitic rocks and continental basement slivers (e.g. Lahondère, 2006; Vitale Brovarone et al., 2011b; Meresse et al., 2012). Metaophiolites are also commonly found as olistostromal bodies intercalated within the meta-sedimentary sequence, and mostly comprise serpentinite and metagabbro blocks, with minor metabasalt and metaophicarbonate (Lagabrielle \& Lemoine, 1997). Metamorphic conditions in this unit increase downwards within the structural pile from $\sim 350^{\circ} \mathrm{C} /$ $1.5 \mathrm{GPa}$ to $\sim 460{ }^{\circ} \mathrm{C} / 1.8 \mathrm{GPa}$ based on Raman spectroscopy on carbonaceous material (RSCM thermometry) estimates and $P-T$ pseudosections (Vitale Brovarone et al., 2013, 2014). The HP metamorphic climax is dated at $c .37 \pm 1.4 \mathrm{Ma}$ by means of Lu-Hf lawsonite geochronology (Vitale Brovarone \& Herwartz, 2013).

The Lawsonite-eclogite unit, which lies structurally below the Lawsonite-blueschist unit, comprises a thicker metaophiolite basement, most notably serpentinite, metabasalt and metagabbro, but also includes a thick meta-sedimentary cover. Slivers of continental basement material (i.e. continental extensional allochtons) are common also in this unit (Lahondère, 2006; Vitale Brovarone et al., 2011b). Peak metamorphic conditions are estimated at $490-550{ }^{\circ} \mathrm{C} /$ 2.2-2.4 GPa (Ravna et al., 2010; Vitale Brovarone et al., 2011a), and were dated at c. $34 \mathrm{Ma}\left[{ }^{40} \mathrm{Ar}^{39} \mathrm{Ar}\right.$ phengite (Brunet et al., 2000); U-Pb zircon (Martin et al., 2011a); Lu-Hf garnet (Vitale Brovarone \& Herwartz, 2013)].

\section{OCCURRENCE AND REGIONAL DISTRIBUTION OF LAWSONITE METASOMATISM}

\section{Lawsonite-blueschist unit}

In this unit, the appearance of lawsonite metasomatites defines a regional metamorphic isograd corresponding systematically to a temperature of $\sim 370{ }^{\circ} \mathrm{C}$ (based on RSCM thermometry) and a pressure of $\sim 1.5 \mathrm{GPa}$ based on regional estimates (Vitale 


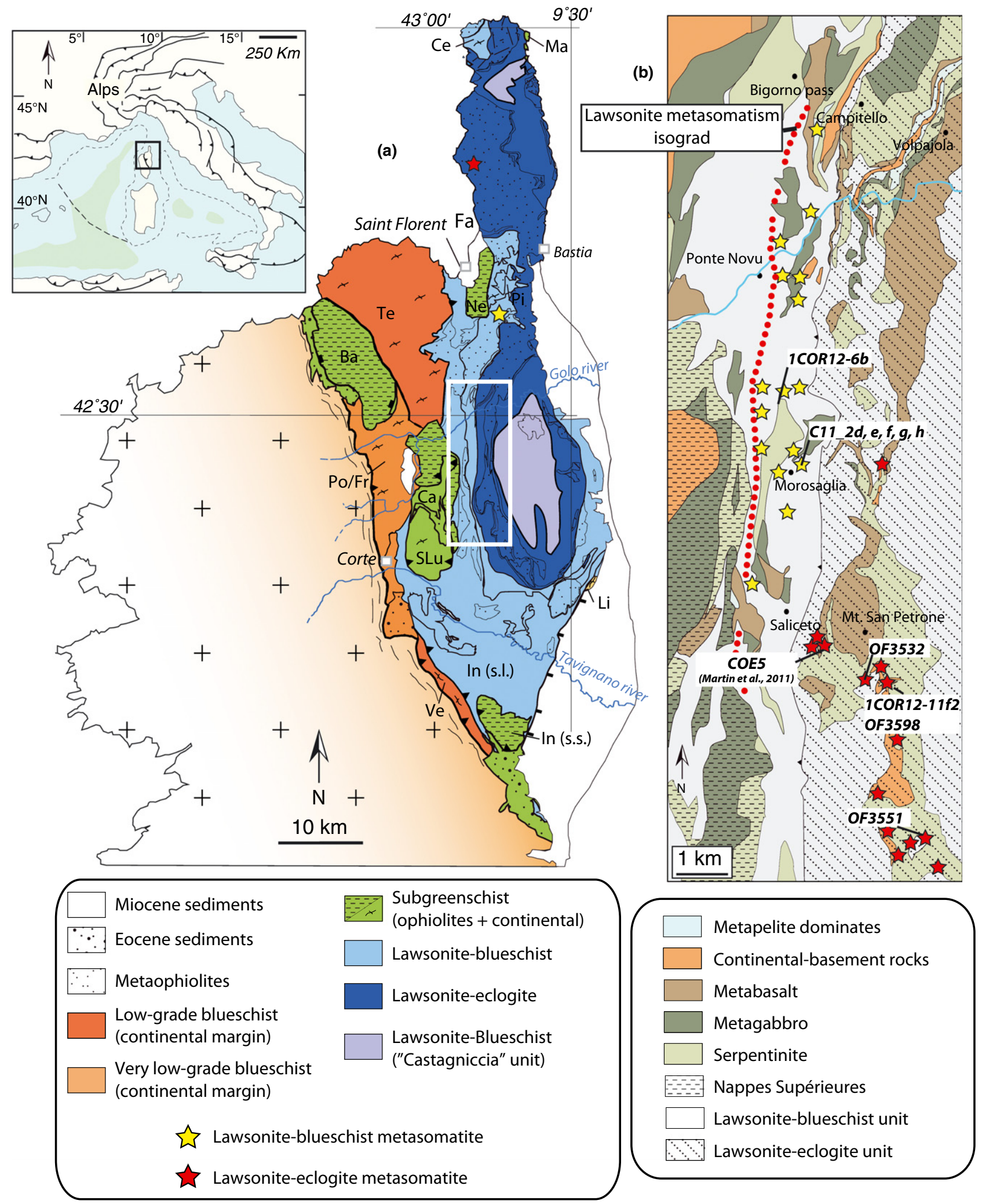

Fig. 1. (a) Simplified metamorphic map of Alpine Corsica. Modified after Vitale Brovarone et al. (2013). (b) Simplified geological map of the study area, cf. (a) for location. Stars refer to the main localities where lawsonite metasomatites were found (total $\sim 200$ finds). 
Brovarone et al., 2014). This isograd is parallel to other mineral isograds found in this unit, e.g. chloritoid. Unlike the other mineral isograds, the appearance of lawsonite metasomatism occurs at higher $P-T$ conditions compared with the first appearance of non-metasomatic lawsonite in favourable lithologies like metabasites. For this reason, its meaning must be seen as indicative of the first $P-T$ conditions at which lawsonite metasomatism formed in the units of Corsica. Lawsonite metasomatites formed at the contact between metamafic/serpentinite/ophicalcite blocks and the enclosing meta-sedimentary rocks, which mostly comprise tuffitic metapelites, minor aluminous metapelites and marble layers. The lawsonite rinds affect the meta-sedimentary rocks only, while different metasomatic products affect the mafic/ serpentinite/ophicarbonate bodies (e.g. tremolite, talc, chlorite). Noticeably, in this unit, lawsonite has been found exclusively in meta-sedimentary rocks affected by metasomatism, and not in meta-sedimentary rocks only affected by regional metamorphism. Over an area of $\sim 6 \mathrm{~km}^{2}$ (Fig. 1a,b), about 200 metasomatic rinds were found around the mafic/serpentinite/ ophicarbonate blocks, and several other lawsonite rinds where found elsewhere within the same unit (Fig. 1b). The thickness of the rinds is proportional to the size of the metaophiolite bodies, and ranges from few centimetres in the case of thin mafic/ serpentinite layers to about $25 \mathrm{~m}$ in the case of large ophiolitic slices. Depending on the lawsonite amount, which reaches up to $\sim 75$ vol. $\%$, rocks affected by metasomatism vary from lawsonite-bearing schists (e.g. 25 vol.\%, samples C11_2d, C11_2e and C11_2f) to massive lawsonite-chlorite fels (e.g. sample 1COR12-6b). Lawsonite forms tabular idioblastic crystals up to $\sim 1 \mathrm{~cm}$ in length. In samples containing $\sim 25$ vol. \% lawsonite, it displays a dark colour due to inclusions of rutile, pyrite and carbonaceous material inherited from the original meta-sedimentary rock (Figs $2 \mathrm{a} \& 3 \mathrm{a}$ ). In other cases, where its modal amount is higher, $\sim 50-75$ vol. \%, metasomatic lawsonite is white and inclusion-poor (Fig. 2b). The matrix mainly consists of chlorite, together with a variable amount of phengite, quartz, albite, blue-amphiboles (glaucophane/ferro-glaucophane, actinolite) and locally Ca-carbonate.

\section{Lawsonite eclogite unit}

In this unit, lawsonite metasomatism occurs at the contact between serpentinites and the overlying metasedimentary rocks or continental basement slivers (Fig. 2c; see Vitale Brovarone et al., 2011b for structural details). Local outcrops of these metasomatic rocks were described by Vitale Brovarone et al. (2011b), and the detailed petrology of one sample by Martin et al. (2011a) (Fig. 1b). Here, we present new observations based on 15 new outcrops found during our recent surveys in different localities of Alpine
Corsica within the Lawsonite-eclogite unit (Fig. 1). Most samples are lawsonitites and range in thickness from some tens of centimetres to about $15 \mathrm{~m}$. Lawsonite content reaches up to $\sim 75 \%$ in volume. In contrast to the Lawsonite-blueschist unit, lawsonite is also common in calcschists far from lithological boundaries and apparently not affected by metasomatism but only by regional metamorphism. However, lawsonite in meta-sedimentary rocks is typically completely or partially replaced by pseudomorphic products (e.g. white mica and epidote-group minerals), whereas lawsonite in metasomatic rinds is very fresh or locally replaced by minor epidote, pumpellyite or carbonate.

Lawsonite metasomatites form at the expense of both continental basement rocks (Type-1) and monometamorphic Mesozoic meta-sedimentary rocks (Type-2) (Martin et al., 2011a; Vitale Brovarone et al., 2011b), and display fels-like textures in both cases. Continental basement rocks and meta-sedimentary rocks along this contact may be extremely variable in composition (e.g. ortho/paragneiss, quartzite, calcschists, marbles), and deciphering a protolith for the lawsonite metasomatites is difficult. Type- 1 metasomatites (Fig. 2d,e) are typically white or greenish in colour, and variations may result from their mineralogical heterogeneity, including variable amounts of chlorite, actinolite, clinopyroxene, mica, blue-amphibole, garnet, pumpellyite and titanite. Clinopyroxene locally forms up to $\sim 5 \mathrm{~cm}$ thick layers or veins parallel to or cutting across the main fabric (Fig. 2e). As a whole, Type-2 lawsonite metasomatites exhibit randomly oriented black, inclusion-rich lawsonite crystals growing on pre-existing compositional layers (Fig. 2f). Clinopyroxene is common both in the matrix of the rock and in vein/bands and confers a yellowish-greenish colour to the rock. In some cases, the rock exhibits dark, lawsonite-rich bands, alternating with green, clinopyroxene-rich veins (e.g. sample OF3551).

\section{METHODOLOGY}

\section{Scanning electron microscopy and electron microprobe}

Petrographic thin sections were carbon coated for scanning electron microscopy (SEM) analyses. Observations were performed at a working distance of $7.5 \mathrm{~mm}$ using a Zeiss Ultra 55 field emission gun SEM operated at $15 \mathrm{kV}$ with a $120 \mu \mathrm{m}$ aperture. Backscattered electron (BSE) mode was used to investigate chemical heterogeneities using an Angle Selective Backscattered Detector (AsB) or an Energy Selective Backscattered Detector (EsB). Energy dispersive X-ray spectrometry (EDXS) maps were acquired using an EDXS QUANTAX system equipped with a silicon drift detector XFlash 4010 (Bruker). Data were processed with the software Esprit (Bruker). 

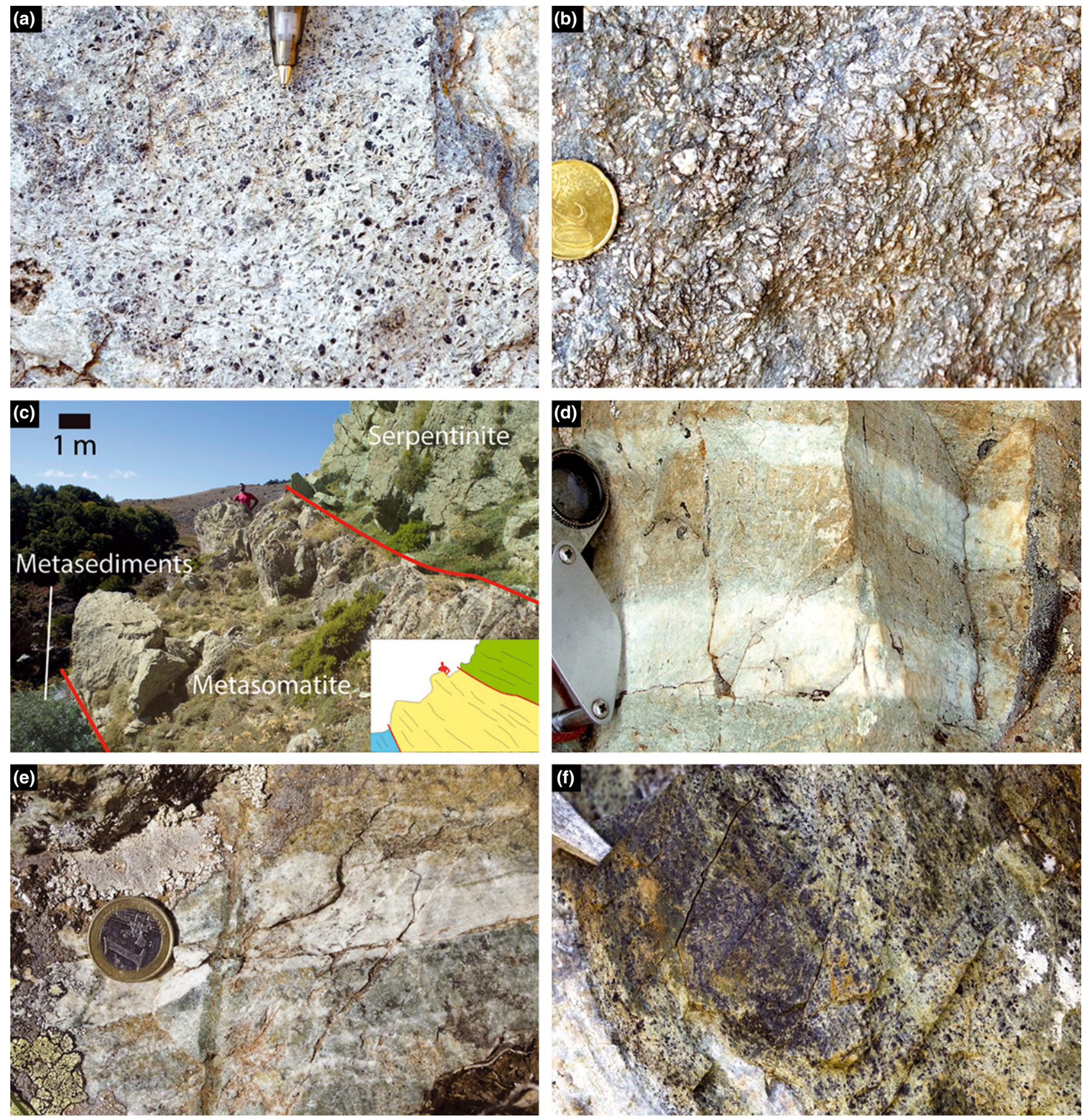

Fig. 2. (a, b) Blueschist facies unit. Lawsonite metasomatites exhibiting different degrees of metasomatism, i.e. 25 vol. $\%$ lawsonite (a) and 75 vol.\% (b) respectively. In (a) (e.g. sample C11 2d), note the inclusion of carbonaceous material and rutile fossilizing the schistosity of the metapelitic protolith. In (b) (e.g. sample 1COR12-6b), the metapelite is almost fully transformed into a lawsonite/ chlorite-rich rock and contains only little relicts of carbonaceous material and rutile. Note that the two samples do not belong to the same rind: (a) formed in contact with metagabbros, and (b) in contact with serpentinites. (c-f) Eclogite facies unit. (c) Example of eclogite facies lawsonite aureole forming at the contact between serpentinites and the overlying rocks, being either metasediment or continental basement rocks. This contact is interpreted to pre-date the Alpine orogeny and to have formed in the Tethyan ocean-continent transition zone (Vitale Brovarone et al., 2011b). (d-e) Example of Type-1 metasomatites formed at the expense of layered continental basement rocks. (d) Outcrop alternating lawsonite- and clinopyroxene-rich layers. In (e), note the small clinopyroxene vein cutting across the rock. (f) Example of Type- 2 metasomatite. The dark mottles consist of inclusion-rich lawsonite (mainly carbonaceous material, sulphides and rutile). The matrix mostly consists of clinopyroxene.

The major elements mineral analyses were performed using a Cameca S-Five and a Cameca-100 electron microprobe (Camparis, Université Paris 6).
Classical analytical conditions were adopted for spot analyses $[15 \mathrm{kV}, 10 \mathrm{nA}$, wavelength-dispersive spectroscopy (WDS) mode], using $\mathrm{Fe}_{2} \mathrm{O}_{3}(\mathrm{Fe}), \mathrm{MnTiO}_{3}$ 

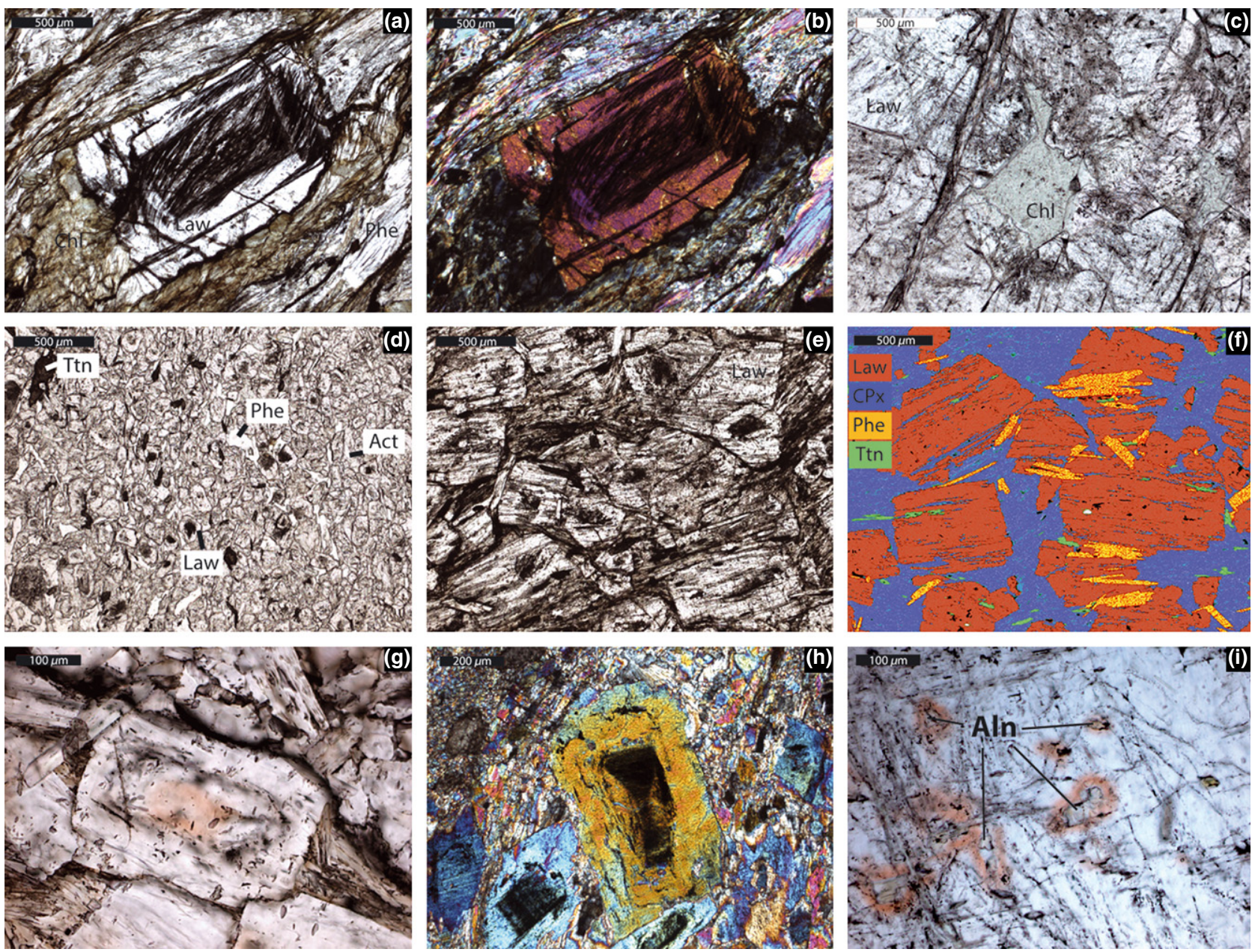

Fig. 3. (a-c) Blueschist facies unit. (a, b) Sample C11_2d. Microphotograph showing the typical microstructure of lawsonite rinds containing $\sim 25$ vol. \% lawsonite. Note the abundant inclusions of carbonaceous material and rutile in lawsonite cores. (c) Microphotograph showing the fels-like texture of lawsonite-rich ( 75 vol.\%) metasomatites (sample 1COR12-6b). This rock mainly consists of lawsonite, chlorite, titanite and quartz. (d-i) Eclogite facies unit. (d-f) This sample (1COR12-11f2) displays a strong grain-size variation. In (e), note the large abundance of tiny lawsonite crystals, together with titanite and phengite. In (e) and (f), note the large lawsonite crystals including the former actinolite-rich fabric. (g) Lawsonite blast displaying reddish REE-rich core in thin section (see also Martin et al., 2011a). (h) Lawsonite blasts including abundant inclusions of carbonaceous material and rutile. These inclusions define hourglass textures and match with the major compositional zoning of lawsonite (Fig. 4b,c). The matrix of the rock mostly consists of clinopyroxene. (1) Close-up of a lawsonite blast including tiny allanite inclusions. The contact between these inclusions and the enclosing lawsonite exhibits reddish rims in thin section, possibly corresponding to pleochroic radiohalos. (a, c, d, e, g, i) Plane-polarized light. (b, h) Cross-polarized light. (f) mixed X-ray compositional map. Mineral abbreviations: chlorite: Chl; lawsonite: Law; phengite: Phe; actinolite: Act; titanite: Ttn; allanite: Aln.

(Mn, Ti), diopside (Mg, Si), orthoclase (Al, K), anorthite $(\mathrm{Ca})$ and albite $(\mathrm{Na})$ as standards. Quantifications were derived from the automated Cameca ZAF quantification procedure.

\section{In situ trace element analyses}

Trace element content of minerals was obtained using a Laser ablation-inductively coupled plasma mass spectrometer (LA-ICP-MS) at Geosciences Montpellier (France). The LA-ICP-MS consists of an excimer Geolas $193 \mathrm{~nm}$ laser coupled to a ThermoFinnigan XR-element ICP-MS. The ICP-MS was operated at $1350 \mathrm{~W}$ and tuned daily to produce maximum sensitivity for the medium and high masses, while keeping the oxide production rate low $\left({ }^{248} \mathrm{ThO} /{ }^{232} \mathrm{Th} \leq 1 \%\right)$. Laser ablation was performed in a pure $\mathrm{He}$ atmosphere $\left(\approx 0.61 \mathrm{~min}^{-1}\right)$ with the following conditions: beam diameter varied between 51 and $77 \mu \mathrm{m}$, depending on mineral size and required spatial resolution, repetition rate and energy density were set at $5 \mathrm{~Hz}$ and $12 \mathrm{~J} \mathrm{~cm}^{-2}$ respectively. Data reduction was carried out using the GLITTER software (Griffin et al., 2008). Internal standard was $\mathrm{Ca}$ or $\mathrm{Si}$, quantitatively analysed by EMP. The NIST 612 glass (Pearce et al., 1997) 


\section{Blueschist-facies}

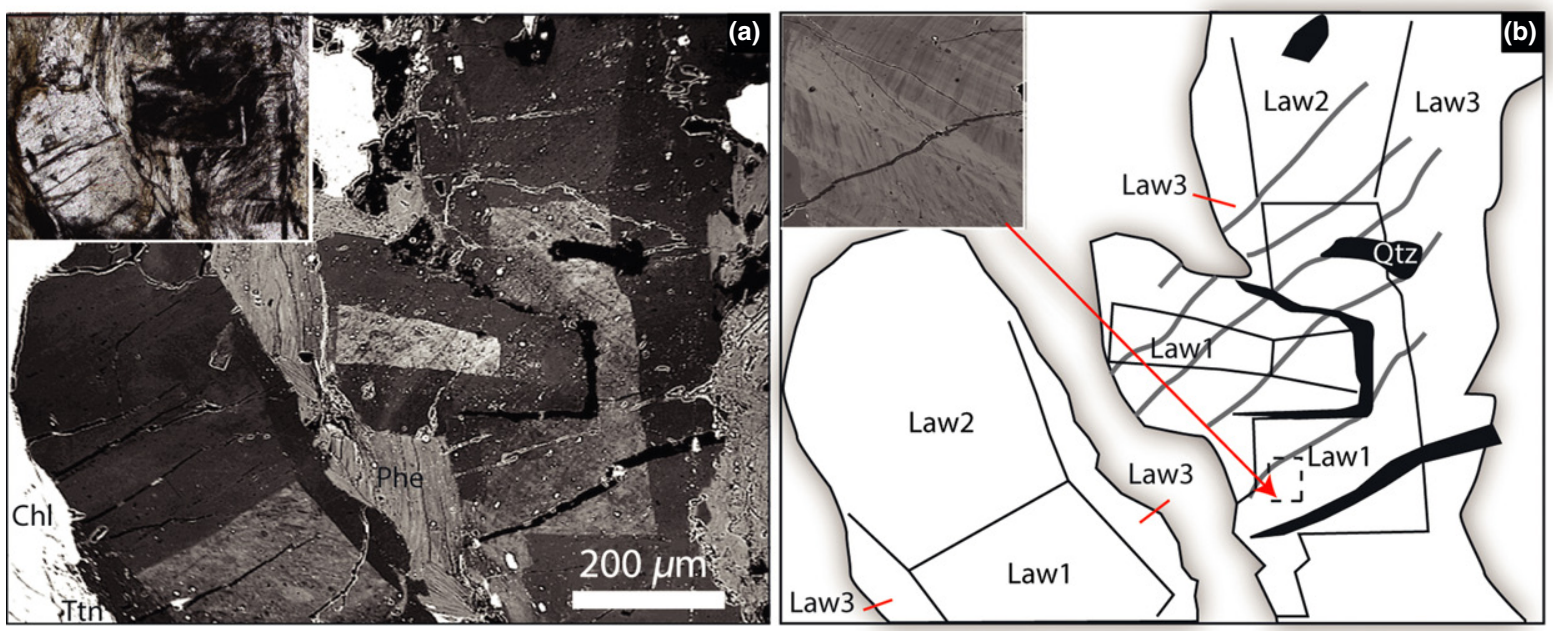

Eclogite-facies
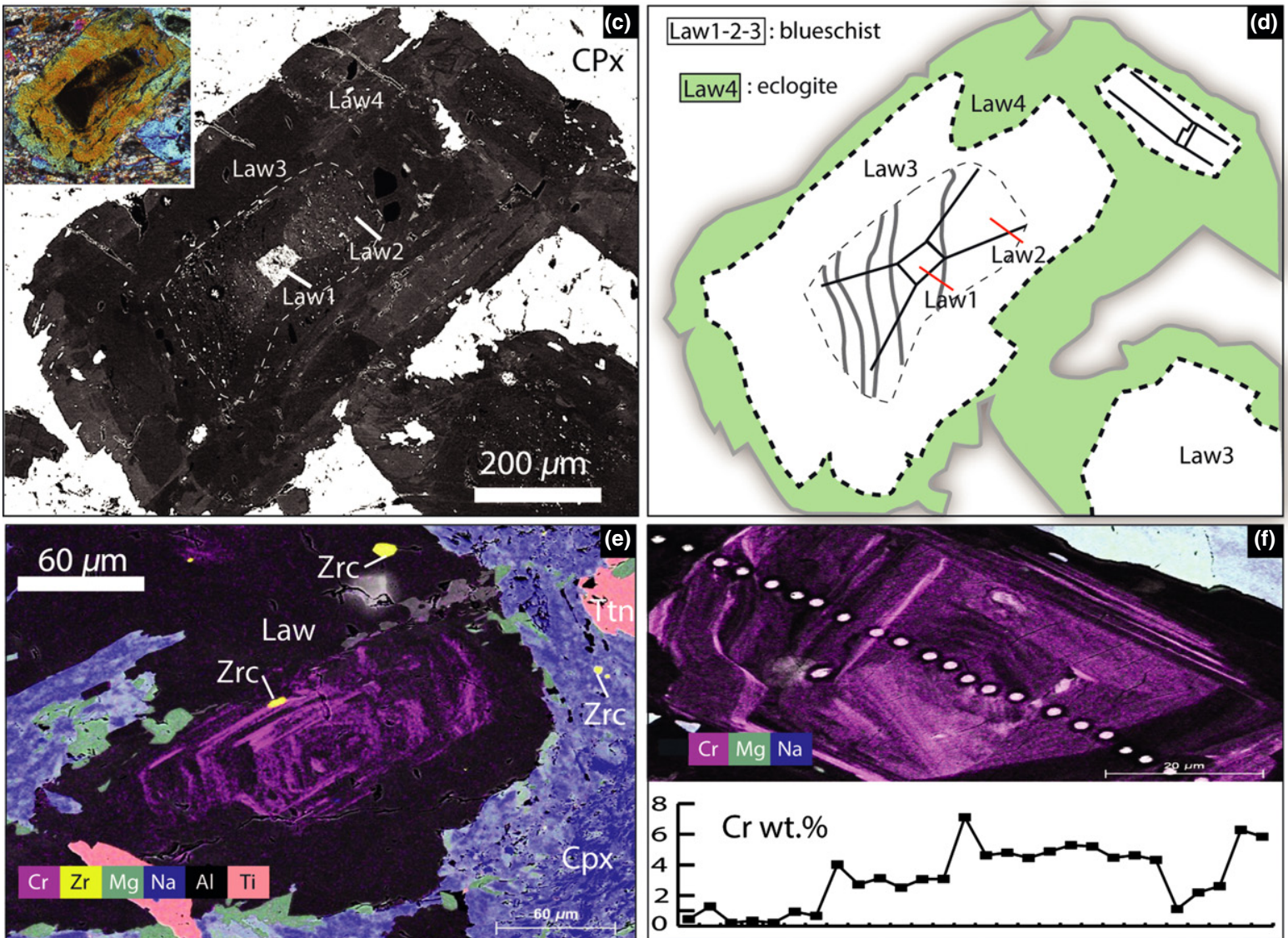

Fig. 4. (a, b) BSE image (a) and simplified sketch (b) of lawsonite zoning in the partially replaced blueschist C11_2d. Three lawsonite crystals occur, two of which are intergrown. Each crystal displays a bright core (Law1) and an intermediate grey zone (Law2) defining hourglass sector zoning, together with a darker rim (Law3). Note that the solid inclusions in lawsonite (mainly rutile, carbonaceous material) occur in both Law 1 and Law2 and, therefore, the brightness of Law 1 is not controlled by the inclusions. Plane-polarized equivalent for reference on top left in (a). In (b), on top left, complex chemical zoning alternating brighter and darker zones in Law1. Note that the inclusion-rich zones, grey lines in (b), do not match with the compositional zoning. (c, d) Compositional zoning (c: BSE; d: sketch) of lawsonite in the eclogite facies sample OF3598. Cross-polarized equivalent in (c), top left. Note the occurrence of similar Law1, Law2 and Law3 textures to the blueschist facies samples, and the occurrence of a fourth zone (Law4) rimming the previous ones. Di: diopside. Note also the complex zoning of Law4. Note the similarity of Law1-Law2 and Law3 in blueschist and eclogite facies metasomatic lawsonite. (e, f) Two examples of Cr oscillatory zoning in vein lawsonite in sample OF3551. In (e), note the occurrence of zircon (Zrc), titanite and clinopyroxene (Cpx), this latter showing complex $\mathrm{Mg}$-Na zoning. In (f), the $\mathrm{Cr}$ content in lawsonite reaches $\sim 8 \mathrm{wt} \%$ (see $\mathrm{Cr}$ compositional profile on the bottom). 
was used as an external standard. This double standardization allows correction for variations in ablation yield and instrumental drift (Longerich et al., 1996). In this paper, and unless otherwise noted, the data reported here are the average of the different analyses $(n)$ for a given phase in a given microstructural occurrence.

\section{Whole-rock analyses and modal amount}

Whole-rock analyses of samples from the Lawsoniteblueschist and Lawsonite-eclogite units (Table 1) were performed at the Service d'Analyse des Roches et Minéraux (SARM, Centre de Recherches Pétrographiques et Géochimiques, Nancy, France)

Table 1. Whole-rock major and trace element analyses. Oxides in $\mathrm{wt} \%$ and trace elements in $\mu \mathrm{g} \mathrm{g}^{-1}$. http://helium.crpg.cnrs-nancy. $\mathrm{fr} / \mathrm{SARM} /$ pages/roches.html for detail on uncertainty and detection limits.

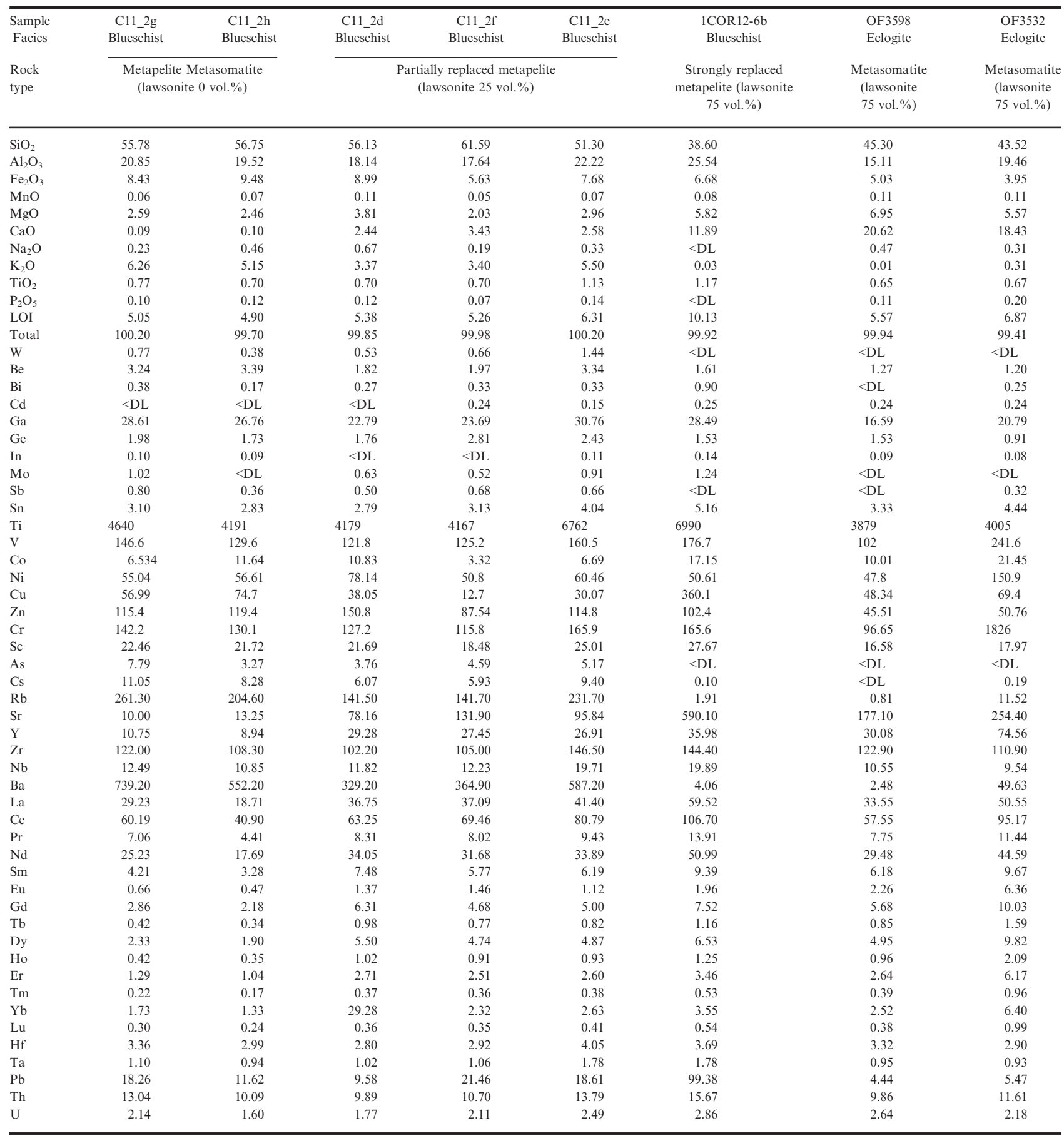


by alkali fusion of rock samples $\left(\mathrm{LiBO}_{2}\right)$, followed by concentration measurements using an ICP-OES Icap 6500 (Thermoscientific) for major elements, and an ICP-MS X7 (Thermoscientific) for minor elements (protocol by Carignan et al., 2001). The modal proportions of minerals in the selected samples were estimated first with optical microscopy and then checked using whole rock and mineral compositions.

\section{SAMPLE DESCRIPTION}

\section{Lawsonite-blueschist unit}

Lawsonite-blueschist metasomatites display petrographic and mineralogical variability from one to another outcrop and within the same rind. To illustrate this, two sets of metasomatites displaying different degrees of metasomatism (partially and extensively replaced, hereafter) are described in detail here. The partially metasomatized samples formed in contact with a metagabbro block (samples C11_2d, e, f) and the extensively metasomatized sample formed in contact with a large serpentinite sliver (samples 1COR12-6a, b). In both cases, the surrounding rocks not affected by metasomatism are metapelites consisting of phengite (40 vol. $\%$ ), chlorite (30 vol.\%,), quartz ( 25 vol. $\%)$, rutile, titanite, carbonaceous material \pm paragonite (all together 5 vol. $\%$ ) as major components (samples C11_2 g \& C11_2 h, Fig. 2b; Table 1). The highest $\mathrm{Si}^{-}$in phengite reaches 3.4 atoms per formula unit (apfu) (Table S1). Chlorite has a constant $X_{\mathrm{Mg}}(=\mathrm{Mg} /(\mathrm{Mg}+\mathrm{Fe})$ atomic ratio $)$ of 0.35 (Table S1).

Carbonaceous matter and tiny acicular rutile are intergrown within phengite and chlorite and define the rock schistosity. Lawsonite does not occur in the pristine metapelite, and all $\mathrm{Ca}(\sim 0.3 \mathrm{wt} \%)$ is entirely hosted in titanite, which forms syn-kinematic idioblasts.

\section{Partially replaced rocks (lawsonite $\sim 25$ vol.\%)}

Samples C11_2d, C11_2e and C11_2f were collected within a $2.5 \mathrm{~m}$ thick metasomatic rind formed in contact with a metagabbro block of $\sim 3 \mathrm{~m}^{3}$ that crops out in the vicinity of the village of Morosaglia (Fig. 2a,c). No serpentinites are observed in this area as they crop out several tens of metres away from this contact. Both samples consist of lawsonite $(\sim 25$ vol. \%), phengite (25 vol.\%) chlorite (25 vol. \%), quartz (15 vol. $\%)$, albite (5 vol. $\%$ ) and minor titanite, rutile, carbonaceous material, apatite and sulphides partially replaced by $\mathrm{Fe}$-oxides (all together 5 vol. \%). Phengite displays high celadonite substitution $(\mathrm{Si}=3.5 \mathrm{apfu})$. Chlorite has a constant $X_{\mathrm{Mg}}$ of 0.4 (Table 2). Aluminium in titanite reaches $\sim 1 \mathrm{wt} \%$ (Table S3). Small relicts of glaucophane were found in pseudomorphic chlorite-albite aggre- gates. Pressure-temperature estimates for the surrounding metapelites unaffected by metasomatism yield an average of $\sim 1.7 \mathrm{Gpa}$ and $\sim 450{ }^{\circ} \mathrm{C}$ (Vitale Brovarone et al., 2013).

Lawsonite occurs as both large (millimetre size) and small (micrometre size) crystals. Larger lawsonite grew statically or syn-kinematically relative to the metapelitic foliation, and is dark in colour owing to abundant mineral inclusions (Figs 2a \& 3a,b). Inclusions consist of carbonaceous material, rutile and sulphides, and mimic the pre-metasomatism fabric of the metapelite (Fig. 3a,b), or form geometrical textural zones, including hourglass textures. Small lawsonite crystals are inclusion-free. In most cases, the textural zoning is defined by inclusion-rich core and inclusion-poor rim, but oscillatory repetitions of inclusion-rich and -poor zones are also observed locally. Large lawsonite also displays chemically zoning defined by darker and brighter zones in BSE imaging. Three main zones were recognized in several crystals, a bright core (Law1), an intermediate mantle (Law2) and a dark rim (Law3) (Fig. 4a,b). The distribution of these zones in the crystals only partly matches with the textural zoning. Law1 occurs exclusively in inclusion-rich zones and, together with Law2 and Law3, forms hourglass-like sector zoning in BSE imaging, and matches the textural zoning described above (Fig. 4a). Compared with standard sector zoning, which are characterized by two distinct zones, here hourglass textures develop from a former core (Law1). In BSE, Law1 also shows thin alternations of brighter and darker zones that seem to mimic the schistosity of the former metapelite (Fig. 4b, top left). Small lawsonite crystals also exhibit compositional zoning in BSE, but displays more scattered patterns.

\section{Extremely replaced rocks (lawsonite 75 vol.\%)}

These rocks (1COR12-6a \& 1COR12-6b) formed in contact with a thick serpentinite slice $(\sim 150 \mathrm{~m})$ in the vicinity of the Morosaglia village. $P-T$ estimates for the surrounding metapelites yield $1.5 \mathrm{Gpa}$ and $\sim 400{ }^{\circ} \mathrm{C}$ (Vitale Brovarone et al., 2014). Both samples consist of lawsonite ( 75 vol. $\%)$, chlorite (15 vol. \%), ferro-glaucophane (10 vol.\%), quartz, white mica, albite, calcite, titanite and tiny epidote crystals (altogether 5 vol.\%) (Fig. 2b). Phengite displays very high celadonite substitution $(\mathrm{Si}=3.6 \mathrm{apfu})$. Chlorite has a rather constant $X_{\mathrm{Mg}}$ of 0.6 (Table S2). Na-amphibole is a ferro-glaucophane (after Leake et al., 1997) and has an $X_{\mathrm{Mg}}$ of 0.5 (Table S4). Titanite Al content reaches $\sim 1.2-1.5 \mathrm{wt} \%$ (Table $\mathrm{S} 3$ ).

In hand specimen, lawsonite occurs as white or grey tabular blasts up to $\sim 2 \mathrm{~cm}$ in length locally forming large aggregates (up to $\sim 5-10 \mathrm{~cm}^{2}$, Fig. 3c), or as tiny crystals. Some crystals contain inclusions of carbonaceous material and acicular rutile, indicating 


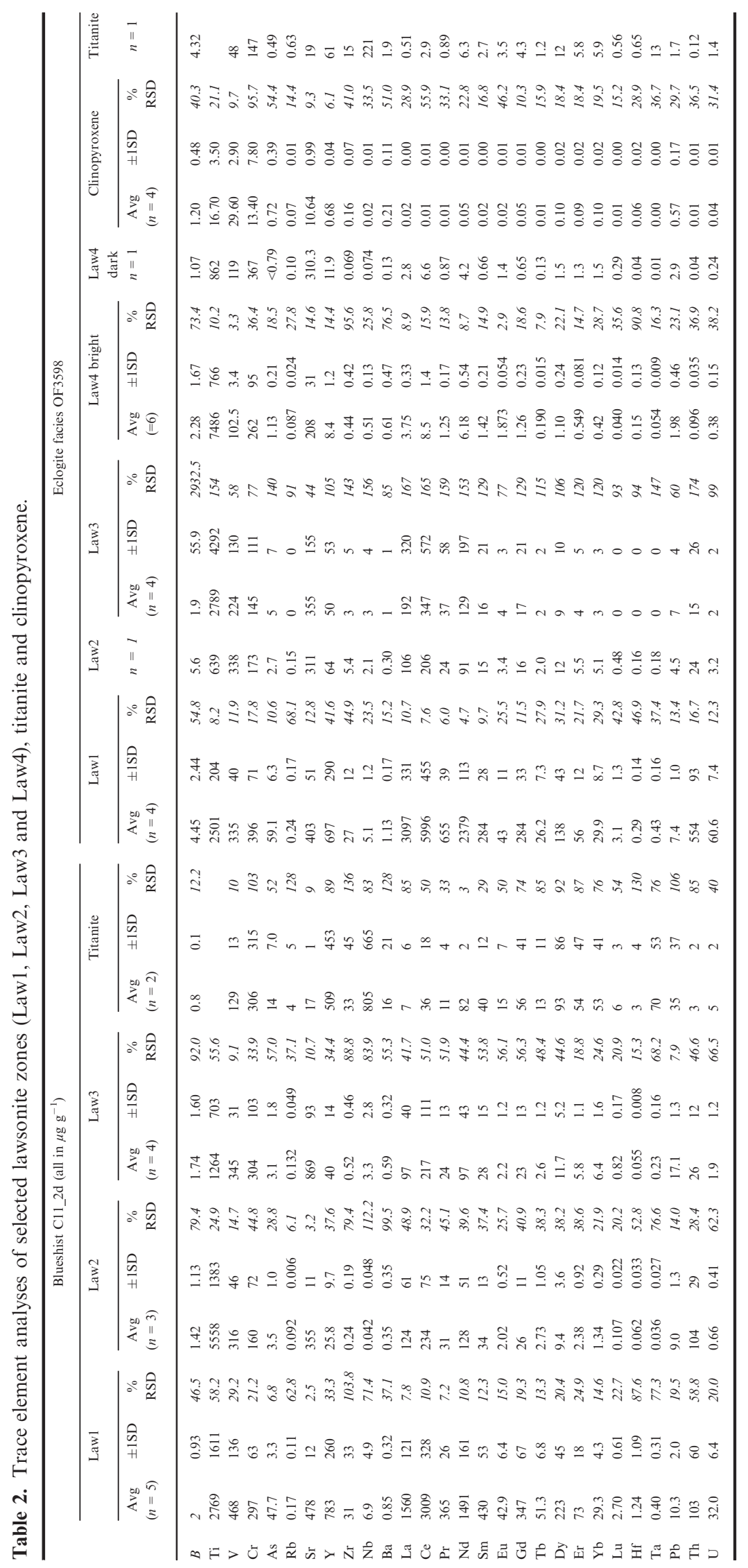


a similar metapelitic protolith with that inferred for the less replaced samples (Fig. 3c). Lawsonite typically shows little zoning compared with sample C11_2e. BSE imaging shows small relicts of Law1 and Law2 zones, but most lawsonite has complex BSE compositional patterns, textures of which suggest multiple lawsonite precipitation/dissolution stages (see next sections) (Fig. S1). These include at least three compositional zones in BSE. Some crystals also exhibit sharp alternations of brighter and darker zones (Fig. S1d). Acicular Na-amphibole occurs as inclusion in quartz together with the smaller lawsonite crystals, as intergrowths with lawsonite or as corroded inclusions in large lawsonite crystals (Fig. S1). In more retrogressed samples, lawsonite is replaced statically by chlorite and albite aggregates. Calcite occurs in some samples as small intergranular aggregates or as large aggregates including euhedral crystals.

\section{Lawsonite eclogite unit}

The eclogite facies lawsonite metasomatites show a wide petrographic variability, possibly inherited from the protolith. Four samples were selected, all containing high or very high lawsonite content (50-75 vol. \%), but displaying different petrological and geochemical features.

\section{Sample 1cor12-11f2 (Type-1)}

This sample is representative of the widely occurring Type- 1 rocks, and was collected $\sim 4 \mathrm{~m}$ from the contact with serpentinites. It consists of lawsonite $(60$ vol. $\%$ ), actinolite (20 vol. \%), phengite (5 vol.\%), chlorite, clinopyroxenes (ranging from QUAD to omphacite in composition (after Morimoto et al., 1988), pumpellyite, titanite, carbonaceous material, rutile and zircon (all together $\sim 15$ vol. \%), but significant modal variations may occur from one to another $\mathrm{cm}$ thick band. The rock displays a marked layering in which alternating layers contain large with small lawsonite crystals, together with a variable amount of other minerals (e.g. actinolite, clinopyroxene, phengite, Fig. 3d,e). Lawsonite grew statically on the protolith fabric as defined by oriented actinolite, which, in some layers, can be followed inside and outside the lawsonite blasts (Fig. 3d-f). Lawsonite locally contains reddish REE-rich core (Fig. 3g; see also Martin et al., 2011a).

\section{Sample OF3598 (Type-2)}

This sample was collected $\sim 10 \mathrm{~m}$ from a large serpentinite body. A thin sliver of continental basement rocks, almost completely transformed into Type-1 lawsonite metasomatites (see sample 1COR12-11f2), occurs between the two rock types. This sample consists of alternating dark, lawsonite-rich layers and light green, clinopyroxene-rich layers. The sample dominantly consists of lawsonite $(\sim 60$ vol. $\%)$ and clinopyroxene (35 vol.\%), together with graphite, titanite, epidote, actinolite, pyrite, apatite and rutile (all together $\sim 5$ vol.\%). Clinopyroxene analyses plot most commonly in the QUAD field. This shows alternating thin rims (few micrometres) with very low $\left(X_{\mathrm{Jd}}=0.5\right)$ or slightly higher $\left(X_{\mathrm{Jd}}=5\right)$ jadeite content, and contains variable amount of ferric iron ranging from $\mathrm{Fe}^{3+} /\left(\mathrm{Fe}^{3+}+\mathrm{Fe}^{2+}\right)=0.05-0.3$ (Table S4). Titanite contains a slightly higher Al content compared with the lawsonite-blueschist facies samples, and reaches $2 \mathrm{wt} \%$. Phengite displays very high celadonite substitution $(\mathrm{Si}=3.6 \mathrm{apfu})$ in all samples.

Lawsonite shows textural and chemical zoning similar to the blueschist facies metasomatic lawsonite. In thin section, crystals have dark cores rich in graphite, rutile and pyrite and inclusion-poor rims (Fig. 3h). These inclusions are similar to those of the blueschist samples formed at the expense of metapelites, and suggest a similar protolith. The inclusion-rich zones are locally fractured and sealed by inclusion-free lawsonite. In some cases, inclusions define hourglass textures (Fig. 3j) that also correspond to chemical sector zoning observed in BSE (Fig. 4c,d), with three compositional zones comparable to the blueschist samples (Law1: bright; Law2: intermediate; Law3: dark). Note that, also in this case, hourglass textures develop from a brighter core. BSE imaging also shows the occurrence of a fourth zone (Law4) forming the outer rim of lawsonite, and being characterized by more complex patterns alternating brighter and darker BSE zones (Fig. 4c,d).

QUAD-clinopyroxene forms randomly oriented aggregates, commonly amygdaloidal. Under high current and contrasted BSE imaging, it exhibits complex oscillatory compositional zoning.

\section{Sample OF3532 (Type-2)}

This sample was collected $1 \mathrm{~m}$ above the contact separating serpentinites and the overlying metasedimentary rocks. It displays a massive layered structure consisting of dominant lawsonite $(\sim 40-50$ vol.\%), strongly oriented clinopyroxene laths (15 vol. $\%$, see sample OF3598 for composition), pale green actinolite (15 vol.\%), together with titanite, phengite, pumpellyite and allanite (altogether $\sim 5-10$ vol.\%). In thin section, the mineral habit suggests precipitation in veins, but this assumption cannot easily be confirmed texturally because of the strong deformation. Lawsonite (up to $0.5 \mathrm{~cm}$ ) displays a pinkish colour in hand specimen, and forms pseudoidioblastic crystals that commonly display reddish mottles in thin section (Fig. 3i). The pinkish colour is due to a high $\mathrm{Cr}$ content in lawsonite (see above), whereas most red patches form at the contact between lawsonite and allanite inclusions, and 
possibly correspond to pleochroic radiohalos (Fig. 3i).

\section{Sample OF3551 (Type-2)}

This sample was collected $\sim 1 \mathrm{~m}$ above the contact with serpentinites. It is a weakly foliated rock characterized by pale green-yellowish matrix consisting of dominant lawsonite, clinopyroxene and quartz, and a green vein consisting of dominant clinopyroxene and minor lawsonite, together with epidote, titanite and zircon as accessory phases. In the matrix, lawsonite forms large blasts containing inclusions of acicular rutile, graphite, pyrite and quartz, and is only slightly oriented parallel to the main rock fabric, which is mainly defined by clinopyroxene. Phengite, titanite, small allanitic epidote, graphite and pyrite are also present in the matrix. The veins are mainly composed of clinopyroxene, which show a variety of textures ranging from fan-shaped to coarse bladed aggregates, all randomly oriented, and display oscillatory zoning alternating pale green with darker green zones. Clinopyroxene in veins of this sample shows a complex compositional zoning including Cr-rich $(\sim 8$ wt $\%)$ and Na-rich $\left(X_{\mathrm{Jd}}=34 \mathrm{~mol} . \%\right)$ zones. Na-rich clinopyroxene has a higher aegirine content ( $X_{\text {Aeg }}$ up to $\sim 10-11 \mathrm{~mol} . \%$ ) relative to $\mathrm{Na}$-poor zones (Table S4), indicating oxidizing conditions during veining. Importantly, both $\mathrm{Cr}$ - and Na-rich zones most commonly occur in the clinopyroxene mantle or rim, and most commonly in veins, where they show an inhomogeneous distribution (see Spandler et al., 2011 for similar patterns). Amphibole in the selected samples is actinolite (after Leake et al., 1997) and has an $X_{\mathrm{Mg}}$ of 0.8 (Table S4).

Lawsonite in veins forms small, commonly elongated sub-idioblastic crystals showing local red, $\mathrm{Cr}$ rich oscillatory zoning detected by BSE imaging and X-Ray compositional maps (Fig. 4e,f, see next sections). Cr-rich zones do not have a specific textural position, and occur either in the core or in the rim of lawsonite, or form scattered patches. The relationships between $\mathrm{Cr}$-rich zones in lawsonite and clinopyroxene are therefore difficult to decipher. Small zircon crystals and allanitic epidote are also present in the veins. This latter mineral occurs both as inclusion in lawsonite and in the matrix, locally forming pleochroic radiohalos similar to those observed in sample OF3532.

\section{BULK ROCK AND MINERAL COMPOSITION}

\section{Lawsonite-blueschist unit}

\section{Whole rock}

Metapelites not affected by lawsonite metasomatism (C11_2g, C11_2h). These rocks have a metapelitic composition with $\mathrm{SiO}_{2}$ of 56-57 wt $\%, \mathrm{Al}_{2} \mathrm{O}_{3}, 20-21$ wt $\%, \mathrm{Fe}_{2} \mathrm{O}_{3}$ (total $\mathrm{Fe}$ as $\mathrm{Fe}_{2} \mathrm{O}_{3}$ ), 9 wt $\%, \mathrm{MgO}, \sim 3 \mathrm{wt}$ $\%$ and $\mathrm{K}_{2} \mathrm{O} \sim 6 \%$. $\mathrm{CaO}(\sim 0.1$ wt $\%)$ and $\mathrm{Na}_{2} \mathrm{O}(\sim 0.2-$ $0.4 \mathrm{wt} \%$ ) are very low (Table 1). Chondrite-normalized REE patterns show a general positive slope with strong light-REE (LREE) enrichment $\left(79 \leq(\mathrm{La})_{\mathrm{N}} \leq\right.$ 123 ; N: chondrite normalized) relative to the heavyREE (HREE), and a sigmoid HREE to mediumREE (MREE) segments. Eu forms a slight negative anomaly $\left(\left(\mathrm{Eu} / \mathrm{Eu}^{*}\right)_{\mathrm{N}} \leq 0.5\right.$; Fig. 5a). Primitive mantle $(\mathrm{PM})$-normalized trace element patterns display an overall enrichment of the large ion lithophile elements (LILE: $\mathrm{Rb}, \mathrm{Ba}, \mathrm{Th}, \mathrm{U}, \mathrm{Pb}, \mathrm{Sr}$ ) relative to the LREE (Fig. 5b), except for $\mathrm{Sr}$, which shows a marked negative anomaly $\left((\mathrm{Sr} / \mathrm{Ce})_{\mathrm{PM}} \leq 0.02\right)$. The high field strength elements (HFSE: Nb, Ta, Zr, Hf, $Y, T i)$ show a non-uniform behaviour relative to the REE. Indeed, while $\mathrm{Nb}$ and $\mathrm{Ta} \pm \mathrm{Ti}$ form a negative anomaly relative to the close REE (e.g. $(\mathrm{Nb} /$ $\left.\mathrm{La})_{\mathrm{PM}} \leq 0.47\right), \mathrm{Zr}$ and $\mathrm{Hf}$ mark a positive anomaly relative to $\mathrm{Sm}\left((\mathrm{Zr} / \mathrm{Sm})_{\mathrm{PM}} \geq 1.22\right)$. $\mathrm{Y}$ displays no anomaly.
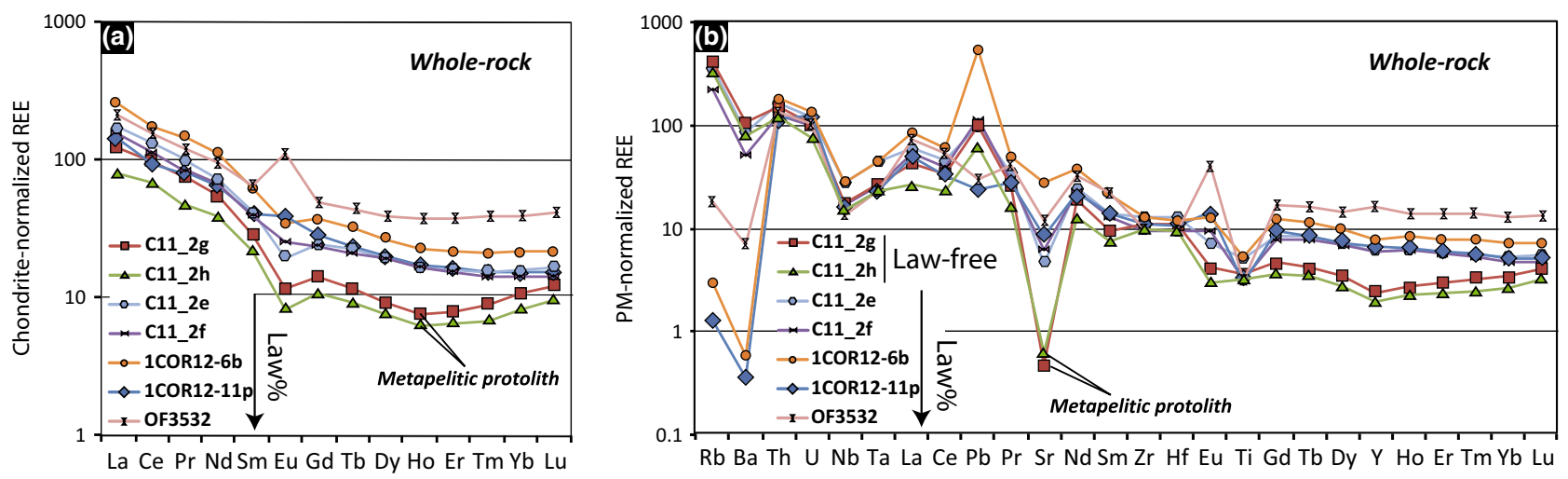

Fig. 5. Whole-rock chondrite-normalized REE patterns (a) and PM-normalized trace element patterns (b) of the selected blueschist and eclogite facies samples. 
Partially replaced rocks (lawsonite 25 vol.\%)

These rocks (samples C11_2d, C11_2e and C11_2f) display similar major element composition to the metapelitic protolith except for a noticeable enrichment in $\mathrm{Ca}(\sim 3 \mathrm{wt} \%)$ and depletion in $\mathrm{K}, \mathrm{Na}$ and $\mathrm{Fe}$ and Mn (Table 1). Overall, these samples have higher concentrations of all trace elements compared with the metapelites (C11_2g \& $\mathrm{C} 11 \_2 h$ ), including Sr, which is enriched by one order of magnitude compared with the metapelites. $\mathrm{Rb}$ and $\mathrm{Ba}$ do not show such enrichment and rather have abundances similar to or slightly lower than that in the metapelites (Fig. 5a,b). While LREE fractionations relative to HREE are comparable to the metapelites, these samples have a steadier REE-normalized slope and do not show a sigmoid HREE to MREE segments. (Eu/ $\left.\mathrm{Eu}^{*}\right)_{\mathrm{N}}$ varies between 0.59 and 0.83 . HFSE display similar abundances (i.e. within range) and behaviour relative to the REE than observed in the metapelite protoliths. Higher $\mathrm{Zr}$ and $\mathrm{Hf}$ and slightly higher Ta, $\mathrm{Nb}$ and $\mathrm{Ti}$ compared with the metapelites also characterize these samples.

\section{Extremely replaced rocks (lawsonite 75 vol.\%)}

Sample 1COR12-6b displays strong major element variations compared with the metapelite protolith C11_2g (Table 1). $\mathrm{SiO}_{2}$ is very low (down to $\sim 38 \mathrm{wt}$ $\%)$, along with strong depletion in $\mathrm{K}_{2} \mathrm{O}(0.03 \mathrm{wt} \%)$ and $\mathrm{Na}_{2} \mathrm{O}[<$ detection limit (DL)]. Iron is slightly lower compared with the metapelites $(6.68 \mathrm{wt} \%)$. $\mathrm{MgO}(5.82 \mathrm{wt} \%)$ and $\mathrm{Al}_{2} \mathrm{O}_{3}(\sim 25.54 \mathrm{wt} \%)$ are higher, whereas $\mathrm{CaO}$ reaches very high content, up to $\sim 12 \mathrm{wt}$ $\%$. The normalized REE pattern of $1 \mathrm{COR} 12-6 \mathrm{~b}$ is parallel to the partially metasomatised samples, but shifted to higher values $\left((\mathrm{La})_{\mathrm{N}}=251\right)$ (Fig. 5a). LILE are also enriched especially $\left.\mathrm{Pb}(\mathrm{Pb} / \mathrm{Ce})_{\mathrm{PM}}=8.94\right)$ and $\mathrm{Sr}(\mathrm{Sr} / \mathrm{Ce})_{\mathrm{PM}}=0.47$ compared to $\mathrm{Sr} / \mathrm{Ce}=0.02$ in the metapellite protolith. The noteworthy exceptions are $\mathrm{Rb}$ and $\mathrm{Ba}$ that are severely depleted relative to the other LILE and to the protolith abundances (Fig. 5b). HFSE show the same behaviour as outlined before.

\section{Lawsonite composition}

Partially replaced rocks (lawsonite 25\%; samples C11_2d, C11_2e, C11_2f)

Lawsonite is close to the ideal composition, but contains little Ti, Al, Cr and locally Mn (Table S1). Electron microprobe analyses reveal a slight variation in $\mathrm{Ti}, \mathrm{Al}$ and $\mathrm{Cr}$ among the three detected lawsonite compositional zones (Law1-Law2-Law3) (Fig. 6). Titanium is higher in Law2 (up to $\sim 0.15 \mathrm{wt} \%$ ) compared with Law1 and Law3 (detection limit, see also next sections), and $\mathrm{Fe}$ increases from Law1 to Law3 $(0.20-0.30 \mathrm{wt} \%)$. Cr is below detection limit in Law1 and Law2 and slightly increases in Law3.
Extremely replaced rocks (lawsonite 75\%) (Sample 1cor126b)

Lawsonite is close to the ideal formula, but it contains $\mathrm{Ti}$ (maximum $\sim 1 \mathrm{wt} \%$ ), little $\mathrm{Fe}$ (maximum $\sim 1$ wt $\%$ ) and little or no Cr (Fig. 7; Table S1). The spatial distribution of Ti-rich zones matches only in part the compositional patterns observed in BSE (Fig. S1). The darkest zones in BSE are commonly the poorest in Ti. The analysed lawsonite crystals do not contain inclusions of Ti-phases $>1 \mu \mathrm{m}$ in size (based on BSE imaging, Fig. S1).

\section{Lawsonite and titanite trace element patterns}

LA-ICPMS analyses (Table 2) of the various lawsonite zones of sample C11-2d $(\mathrm{Law}=25 \%)$ show that despite large variation, all lawsonite types have extremely high abundances of REE, with $\mathrm{Yb}$ and $\mathrm{La}$ varying from $1.34 \mathrm{up}$ to $29.3 \mathrm{\mu g} \mathrm{g}^{-1}$ and between 97 and $1560 \mu \mathrm{g} \mathrm{g}^{-1}$ respectively. Such REE concentrations are significantly higher than most previously published lawsonite analyses of natural and synthetic origins (e.g. Tribuzio et al., 1996; Ueno, 1999; Spandler et al., 2003; Usui et al., 2007; Martin et al., 2011 b, 2014), and are only slightly higher or in the range of the previously studied lawsonitites sample from Corsica (Martin et al., 2011a).

Despite an order of magnitude of difference in REE concentration between Law1 $\left((\mathrm{Yb})_{\mathrm{N}}=182 \pm 27\right)$ and Law2 $\left((\mathrm{Yb})_{\mathrm{N}}=40 \pm 10\right)$, the two types have remarkably similar REE patterns (Fig. 6a). These patterns are characterized by an overall enrichment from the HREE to the LREE, marked by Eu-negative anomalies $\left(\left(\mathrm{Eu} / \mathrm{Eu}^{*}\right)_{\mathrm{N}}=0.3 \pm 0.1\right)$, and steeper HREEMREE segments (e.g. $\left.(\mathrm{Gd} / \mathrm{Lu})_{\mathrm{N}}=23 \pm 12\right)$ than the MREE-LREE segments $\left((\mathrm{La} / \mathrm{Sm})_{\mathrm{N}}=3 \pm 1\right)$. Law3 zones have similar REE abundances to the Law2 zones except for the HREE (Er, $\mathrm{Yb}$, and $\mathrm{Lu}$ ), which are higher in Law3 and have a less fractionated REE pattern $\left((\mathrm{Gd} / \mathrm{Lu})_{\mathrm{N}}=3 \pm 2\right)$. The REE pattern of Law3 is the same as the whole-rock pattern.

All lawsonite types have PM-normalized trace element patterns marked by strong HFSE and Rb-Ba negative anomalies relative to the neighbouring REE (Fig. 6b). However the abundances and fractionation of the other LILE ( $\mathrm{U}, \mathrm{Th}, \mathrm{Pb}$ and $\mathrm{Sr}$ ) show strong variation as a function of the microstructural characteristic of the lawsonite (Fig. 6b,e,f). Law1 shows strong negative anomalies of $\mathrm{Pb}$ and $\mathrm{Sr}$ relative to the LREE $\left(0.02<(\mathrm{Pb} / \mathrm{Ce})_{\mathrm{PM}} \leq 0.04, \quad 0.01<(\mathrm{Sr} / \mathrm{Ce})_{\mathrm{PM}} \leq 0.04\right)$; these negative anomalies are greatly reduced in Law3 (Fig. 6e). Whereas $\mathrm{U}$ and Th show relatively high abundances for all lawsonite zones, the U-Th fractionation varies significantly $\left(0.02<(\mathrm{U} / \mathrm{Th})_{\mathrm{PM}} \leq 2.69\right)$ amongst and within the lawsonite type (Fig. 6b,f). These LILE fractionations show complex patterns relative to the REE (Fig. 6e,f). As shown by microprobe analyses, Law2 has higher $\mathrm{Ti}\left(\mathrm{Ti}_{\mathrm{N}}=4\right)$ compared with 

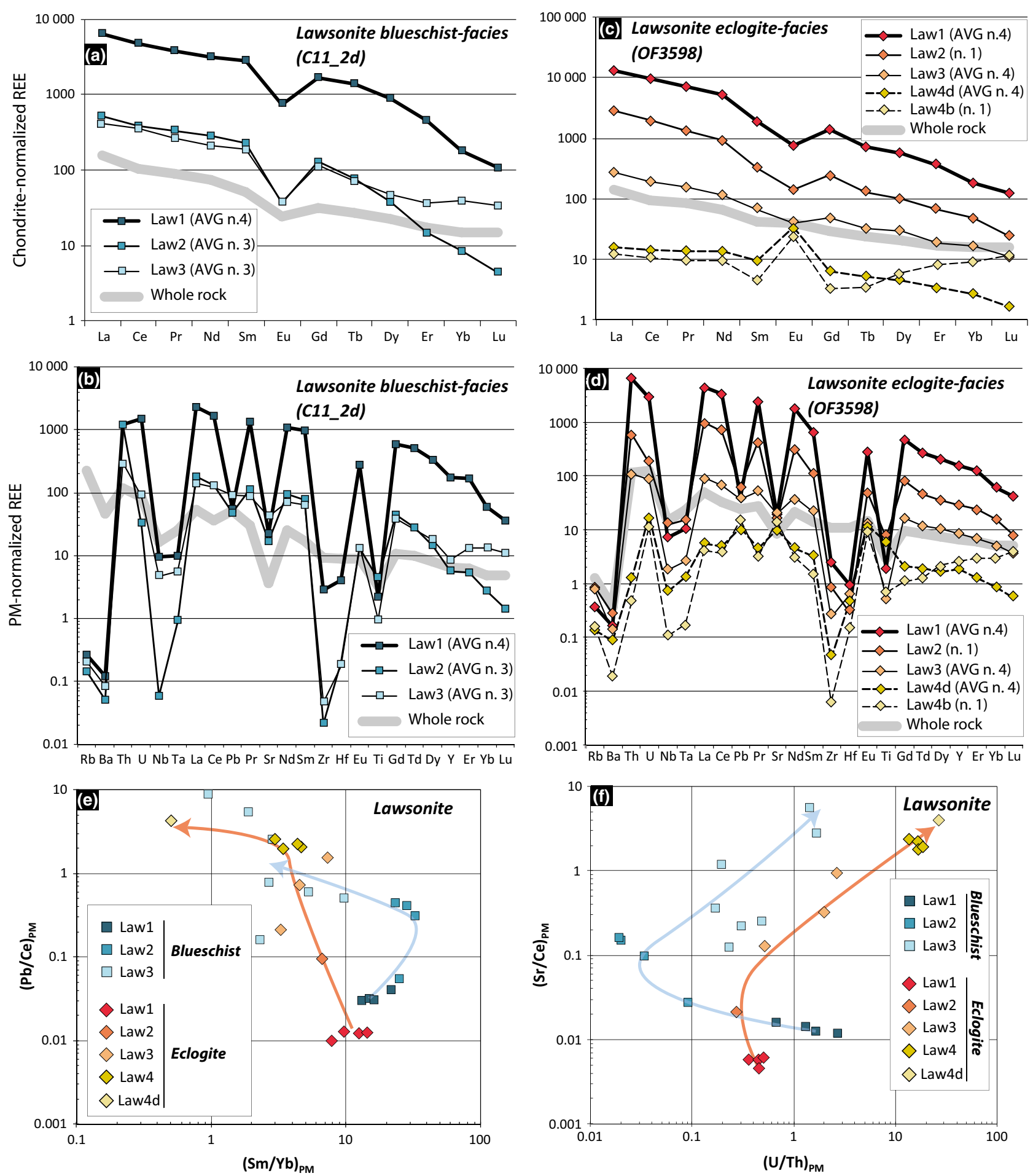

Fig. 6. (a-d) Chondrite-normalized REE patterns (a, c) and PM-normalized trace element patterns (b, d) of lawsonite zoning (Law1, Law2, Law3 and Law4) in the selected blueschist (a, b) and eclogite facies (c, d) samples. Note that Law4 occurs uniquely in eclogite facies samples $(\mathrm{c}, \mathrm{d})$. (e, f) Variations of the $(\mathrm{Pb} / \mathrm{Ce})_{\mathrm{PM}} v s$. $(\mathrm{Sm} / \mathrm{Yb})_{\mathrm{PM}}$ ratios $(\mathrm{e})$ and $(\mathrm{Sr} / \mathrm{Ce})_{\mathrm{PM}} v s$. $(\mathrm{U} / \mathrm{Th})_{\mathrm{PM}} \mathrm{ratios}(\mathrm{e})$ in the different lawsonite zones of blueschist and eclogite facies samples.

Law1 $\left(\mathrm{Ti}_{\mathrm{N}}=2\right)$ and Law1 $\left(\mathrm{Ti}_{\mathrm{N}}=1\right)$. The $\mathrm{B}$ content is rather constant from Law1 to Law3, and ranges from 1.4 to $2 \mu \mathrm{g} \mathrm{g}^{-1}$.
Titanite in sample C11_2d displays a convex chondrite-normalized REE pattern, with high HREE/ LREE ratios $\left((\mathrm{Lu} / \mathrm{La})_{\mathrm{N}}=8\right)($ Fig. $\mathrm{S} 1)$. PM-normalized 
Fig. 7. Ternary diagram showing the variation of the $\mathrm{Al}$ substitution in lawsonite compositional zones (Law1, Law2, Law3 and Law4) by $\mathrm{Fe}, \mathrm{Cr}$ and $\mathrm{Ti}$ for different extents of metasomatism and metamorphic conditions. Lawsonite volume proportions are indicated in the legend (e.g. Law75\%). Maximum content of each element is reported in atoms per formula unit (apfu) in the corners. Titanium is richer in lowgrade and highly replaced rocks, while Fe and $\mathrm{Cr}$ tend to increase with metamorphic conditions.

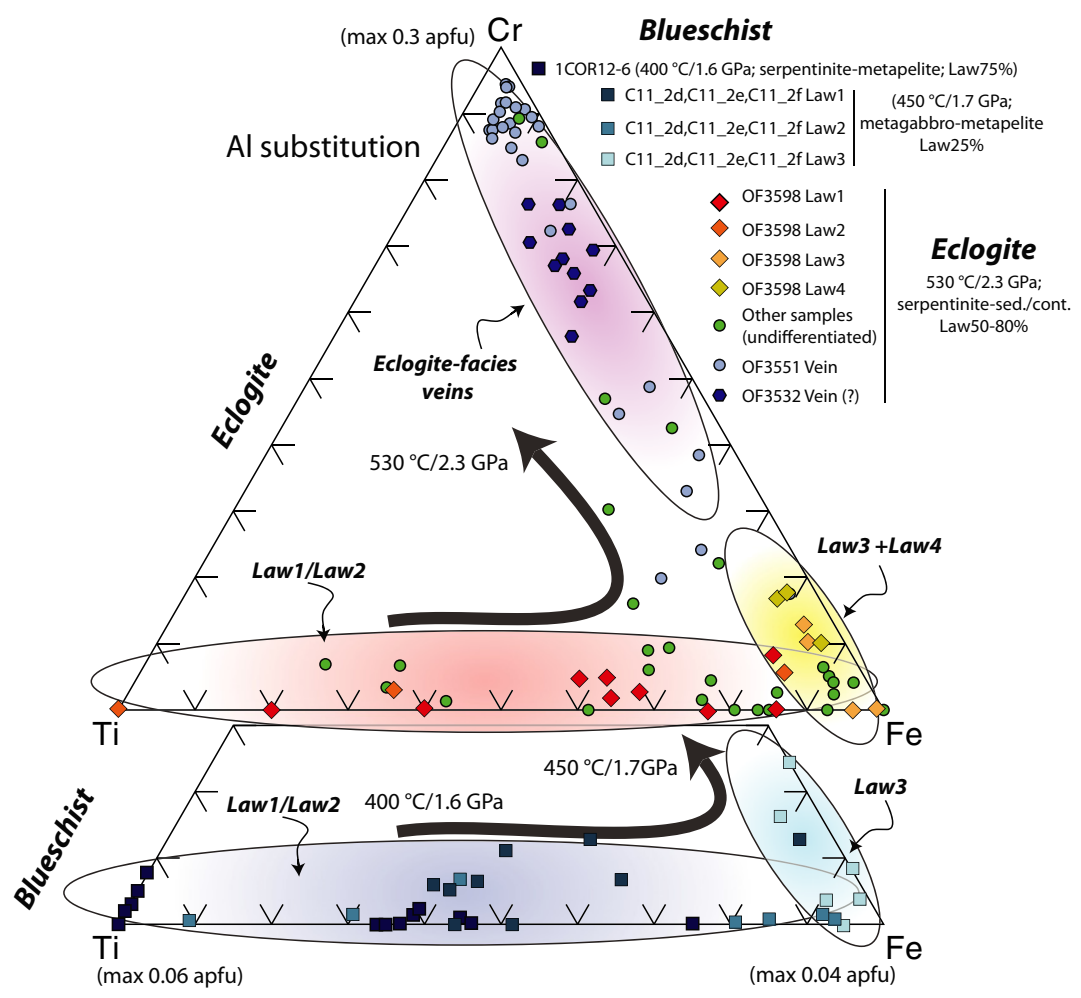

trace element patterns show a distinct HFSE-positive anomaly, except for $\mathrm{Zr}$ and $\mathrm{Hf}$, which show negative anomaly relative to MREE (Fig. S1). LILE display negative anomaly, except for $\mathrm{Pb}$. B is very low $\left(0.8 \mu \mathrm{g} \mathrm{g}^{-1}\right)$.

\section{Lawsonite eclogite unit}

\section{Whole rock}

Due to the high lithological variability of the protolith, an unambiguous identification of the precursor composition for these rocks prior to metasomatism was not possible during our field study. Samples OF3598 and OF3532 display low $\mathrm{SiO}_{2}(\sim 44 \mathrm{wt} \%)$, high $\mathrm{CaO}$ and $\mathrm{MgO}(\sim 19 \mathrm{wt} \%$ and $6 \mathrm{wt} \%$ respectively), low $\mathrm{Na}_{2} \mathrm{O}(0.4 \mathrm{wt} \%)$ and very low $\mathrm{K}_{2} \mathrm{O}$ (0.01-0.3 wt\%) (Table 1). Whole-rock composition of sample OF3551 was not obtained owing to the occurrence of veins, but modal amounts of major minerals in the host rock suggest a composition similar to sample OF3598, but higher quartz modal proportions suggest higher $\mathrm{SiO}_{2}$.

Chondrite-normalized REE patterns of the two analysed samples show a similar trend to the blueschist samples except for a positive Eu anomaly $((\mathrm{Eu} /$ $\left(\mathrm{Eu}^{*}\right)_{\mathrm{N}}$ up to 2.0) (Fig. 5a). Sample OF3532 has higher HREE concentration compared with all other studied samples $\left((\mathrm{Lu})_{\mathrm{N}}=40\right)$. PM-normalized trace elements display $\mathrm{Rb}$ - and Ba-negative anomaly, same as the blueschist facies metasomatites (Fig. 5b). Sr displays high concentration $\left(8.39<(\mathrm{Sr})_{\mathrm{N}}<12.06\right)$ compared with a metapelitic reference (C11_2 g, $\left.\mathrm{C} 11 \_2 \mathrm{~h},(\mathrm{Sr})_{\mathrm{N}}=0.55\right)$. HFSE patterns are comparable to all studied samples. Sample OF3532 displays very high $\mathrm{Cr}\left(1826 \mu \mathrm{g} \mathrm{g}^{-1}\right)$ and $\mathrm{Ni}\left(159 \mu \mathrm{g} \mathrm{g}^{-1}\right)$ compared with the average composition of the surrounding rock types (meta-sedimentary rocks, felsic rocks and metaophiolites), except for serpentinites (see e.g. Deschamps et al., 2013).

\section{Lawsonite and titanite trace element patterns}

Lawsonite LA-ICP-MS in situ trace element analyses were performed on sample OF3598. The four lawsonite compositional zones recognized in BSE (Law1-4) display different compositional patterns (see Sample description and Fig. 6c,d). Law1 and Law2 chondrite-normalized REE and PM-normalized patterns are comparable to Law1 and Law2 of the blueschist facies lawsonite, with an overall enrichment from the HREE to the LREE, and marked by Eu-negative anomalies $\left(0.46<\left(\mathrm{Eu} / \mathrm{Eu}^{*}\right)_{\mathrm{N}}<0.49\right)$ and large HFSE and $\mathrm{Rb}-\mathrm{Ba}$-negative anomalies. Law3 displays similar pattern, but differs from the blueschist facies Law3 in having a smaller negative $\mathrm{Eu}$ anomaly $((\mathrm{Eu} /$ $\left.\left.\mathrm{Eu}^{*}\right)_{\mathrm{N}}=0.76\right)$, and a steeper HREE slope $((\mathrm{Gd} /$ $\mathrm{Lu})_{\mathrm{N}}=5.1 \pm 1.4$ vs. $3 \pm 1$ in the blueschist Law3). From Law1 to Law3, $\mathrm{Pb}$ and $\mathrm{Sr}$ show a progressive shift from strong $\left((\mathrm{Pb} / \mathrm{Ce})_{\mathrm{PM}}=0.01 ; \quad(\mathrm{Sr} /\right.$ $\left.\mathrm{Ce})_{\mathrm{PM}}=0.01\right) \quad$ to $\quad$ low $\quad\left((\mathrm{Pb} / \mathrm{Ce})_{\mathrm{PM}}=0.83 ; \quad(\mathrm{Sr} /\right.$ $\mathrm{Ce})_{\mathrm{PM}}=0.46$ ) negative anomalies (Fig. 6d). Law4 
displays more complex patterns, with HREE varying from positive $\left((\mathrm{Gd} / \mathrm{Lu})_{\mathrm{N}}=4.2\right)$ to negative slopes $\left((\mathrm{Gd} / \mathrm{Lu})_{\mathrm{N}}=0.3\right)$, but all have a distinct Eu-positive anomaly $\left(4.3<\left(\mathrm{Eu} / \mathrm{Eu}^{*}\right)_{\mathrm{N}}<6.3\right)$. $\mathrm{Pb}$ and $\mathrm{Sr}$ display further increase, yielding a positive anomaly $\left(2.2<(\mathrm{Pb} / \mathrm{Ce})_{\mathrm{PM}}<4,2 ; \quad 2.1<(\mathrm{Sr} / \mathrm{Ce})_{\mathrm{PM}}<4.0\right) . \quad \mathrm{Rb}$ and $\mathrm{Ba}$ show enrichment from Law1 to Law2, followed by a sharp decrease in Law3 and Law4. U/Th fractionation displays variable values in Law1 ((U/ $\left.\mathrm{Th})_{\mathrm{PM}}=0.5\right)$, Law2 $\left((\mathrm{U} / \mathrm{Th})_{\mathrm{PM}}=0.7\right)$ and Law3 $((\mathrm{U} /$ Th) $\left.)_{\mathrm{PM}}=1.8\right)$, and major increase in Law4 $\left(16.2<(\mathrm{U} / \mathrm{Th})_{\mathrm{PM}}<22.5\right)$ (Fig. 6f). Boron displays scattered patterns, with higher values in Law1-2 (4.5-5.6 $\left.\mu \mathrm{g} \mathrm{g}^{-1}\right)$ than in Law3-4 $\left(1-2.3 \mu \mathrm{g} \mathrm{g}^{-1}\right)$. The lowest B content is observed in the darkest Law4.

Titanite in sample C11_2d displays a convex chondrite-normalized REE pattern, with HREE/LREE ratios $\left((\mathrm{Lu} / \mathrm{La})_{\mathrm{N}}=10.6\right)$ similar to the blueschist facies sample, but here has a positive $\mathrm{Eu}$ anomaly $\left((\mathrm{Eu} / \mathrm{Eu} *)_{\mathrm{N}}=3.1\right) \quad$ (Fig. S2). PM-normalized trace element patterns are similar to the blueschist facies rocks, but display less marked $\mathrm{Sr}, \mathrm{Zr}$ and $\mathrm{Hf}$ negative anomalies (Fig. S2). The B content in titanite reaches $\sim 4 \mathrm{~g} \mathrm{~g}^{-1}$ (Table 2).

\section{MASS CHANGE DURING METASOMATISM}

Field and microstructural evidence indicates that, in the Lawsonite-blueschist unit, lawsonite metasomatites formed at the expense of a metapelitic protolith such as samples C11_2 g and C11_2 h. Mass changes for major element during metasomatism of these samples were calculated following the approach of Grant (2005) (see also van der Straaten et al., 2012) (Fig. 8).

In partially replaced samples ( 25 vol. \% lawsonite), most major elements cluster near the $1: 1$ line, except for $\mathrm{Ca}$, which displays mass gain $>3000 \%$ (note the very low $\mathrm{Ca}$ content in the metapelitic protolith), and $\mathrm{Mn}(-10 \%), \mathrm{Fe}$ and $\mathrm{Na}$ (both $-25 \%$ ), which show mass loss. Trace elements show much more complex trends, but with a general mass gain. HFSE are near 1:1 for $\mathrm{Hf}$ and $\mathrm{Zr}$, while they experienced mass gain up to $\sim+40 \%$ for $\mathrm{Ta}, \mathrm{Nb}$ and $\mathrm{Ti}$, and up to $+70 \%$ for Y. LREE display common mass gain at $\sim+50 \%$.

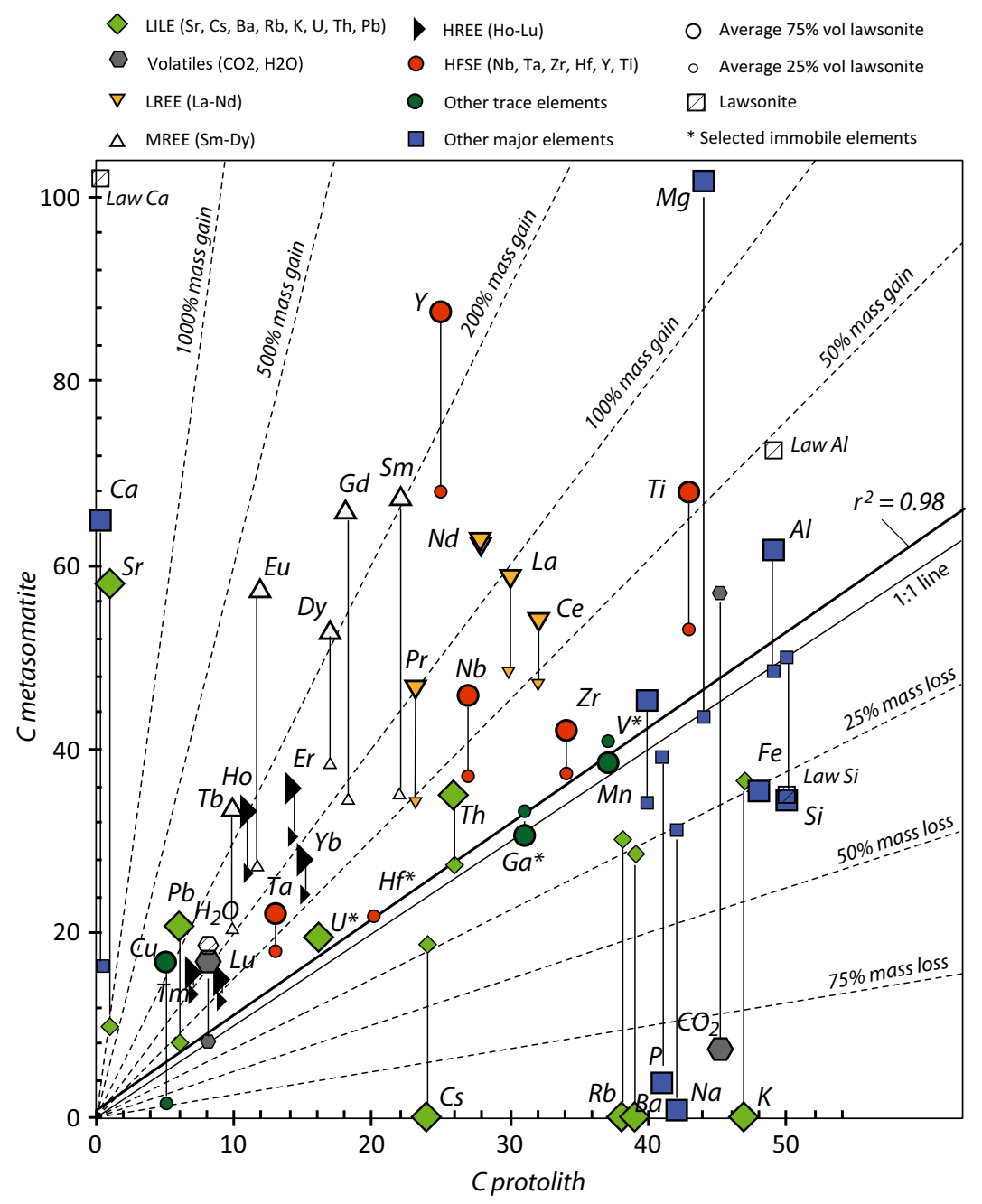

Fig. 8. Isocon diagram showing mass change trends of major and trace elements of two sets of samples displaying partial (small symbols; average of samples containing $\sim 25$ vol.\% lawsonite: C11_2d, e, f) and strong (large symbols; $\sim 75$ vol. $\%$ lawsonite: 1COR12-6b) replacement compared with the metapelites not affected by lawsonite metasomatism $\left(\mathrm{C} 11 \_2 \mathrm{~g}, \mathrm{~h}\right)$. Following the approach of Grant (2005), the isocon is based on the slope of $C_{i}^{A} / C_{i}^{O}$ $\left(C_{i}^{A}\right.$ and $C_{i}^{O}$ are the concentration of species $i$ in the Altered and the Original rock respectively). The slope of the isocon is based on immobility of U, V, Ga and Hf, which do not show significant variation during metasomatism and cluster near 1 $\left(r^{2}=0.98\right)$. Data are scaled to even values in decreasing concentration, from major elements to trace elements, except for $\mathrm{CaO}$, $\mathrm{Sr}$ and $\mathrm{H} 2 \mathrm{O}$ that are scaled to lower values because of the strong variations. Layout inspired by van der Straaten et al. (2012). Lawsonite composition is also plotted for reference. 
MREE cluster from $\sim 60 \%(\mathrm{Sm})$ to $\sim+100-120 \%$ (Gd, Dy, Eu, Tb). HREE plot between $+40(\mathrm{Lu})$ and $+150 \%$ (Ho). LILE show different trends with $\mathrm{U}$ and Th near $1: 1, \mathrm{Cs}, \mathrm{Ba}, \mathrm{Rb}, \mathrm{K}$ and $\mathrm{Pb}$ with constant mass loss of $\sim-25 \%$, and $\mathrm{Sr}$ with very high mass gain at $\sim+1000 \%$.

In extremely replaced samples (75 vol.\% lawsonite), trends of mass change are similar to those of the partially replaced ones, but shifted towards higher values. $\mathrm{Ca}$ increases further $\left(>10^{4} \%\right)$, and $\mathrm{Fe}$ and $\mathrm{Na}$ are depleted to $-35 \%$ and $-80 \% \mathrm{Al}$ and $\mathrm{Mg}$, which were close to $1: 1$ in less metasomatized samples, show a mass gain up to $\sim+25 \%$ and $+70 \%$ respectively. Most HFSE ( $\mathrm{Ta}, \mathrm{Nb}, \mathrm{Zr}, \mathrm{Ti}$ and $\mathrm{Y}$ ) experienced further mass gain up to $\sim+60-75 \%$, or $+90 \%$ for $\mathrm{Y}$, and $\mathrm{Hf}$ is near 1:1. REE display further mass gain, especially for MREE, which gain up to $+150 \%$ compared with the partially replaced samples. $\mathrm{Eu}$ and $\mathrm{Gd}$ show the highest mass gain $(\sim+400 \%$ and $+300 \%$ respectively). Among LILE, $\mathrm{Sr}$ and $\mathrm{Pb}$ also show high and very high mass gain, up to $+200 \%$ and $>10,000 \%$ respectively; Th increases up to $\sim+40 \%$, $\mathrm{U}$ is near $1: 1$ and univalent LILE $(\mathrm{Cs}, \mathrm{Rb}$, $\mathrm{Ba}$ and $\mathrm{K}$ ) display a common high decrease near $-100 \%$ (Fig. 8). Mass gain in $\mathrm{H}_{2} \mathrm{O}$ reaches $\sim 200 \%$.

The above mass change patterns summarize lawsonite metasomatism under blueschist facies conditions. At higher $P-T$ in the Lawsonite-eclogite unit, precise mass change calculation was not possible owing to the uncertainty on the protolith composition, but the main major and trace element patterns suggest similar processes. In addition, textural and compositional features indicate additional element mobilization/fluid influx at higher $P-T$ conditions, including at least $\mathrm{Cr}$ and $\mathrm{Na}$ mass gain (see previous section). A further increase of $\mathrm{Eu}$ is also expected in eclogite facies conditions because of the distinct whole-rock positive anomaly in all analysed eclogite facies samples (Fig. 5a,b).

\section{DISCUSSION}

\section{Global significance and HP metamorphic conditions of lawsonite metasomatism}

Apart from Alpine Corsica, reports of lawsonite metasomatites are limited to a tectonic block included in a serpentinite mélange in Guatemala (Tsujimori \& Ernst, 2014), and rare chlorite-lawsonite-rich rocks at the contact between serpentinites and the overlying metabasalts in the HP terranes of the Tavşanll Zone, Turkey (Zack, 2013). Despite this apparent rarity, several arguments suggest that these rocks may be common at HP conditions in subduction zones. As an example, the wide $P-T$ conditions at which the Corsican lawsonitites formed $\left(350-550{ }^{\circ} \mathrm{C} / 1.5-2.3 \mathrm{GPa}\right)$ are comparable to the $P-T$ conditions of several other exhumed HP/LT metamorphic rocks of oceanic affinity (e.g. Agard et al., 2009 for review) (Fig. 9). There- fore, these rocks or their pseudomorphic products may occur in other HP/LT belts. Noticeably, fully retrogressed lawsonite-rich rocks are described in similar settings in the Western Alps (Angiboust et al., 2011). Moreover, epidote-rich rocks in retrogressed lawsonite-blueschist blocks in serpentinites in the Kurosegawa zone (Japan) may also represent a suitable case study (Miyazoe et al., 2012).

Robust field, textural and geochemical evidence supports the idea that this type of Ca-rich metasomatism occurred at HP conditions during subduction, rather than prior to subduction, e.g. during seafloor hydrothermal alteration. Field observations and $P-T$ estimates indicate that lawsonite metasomatism occurs in rocks that experienced at least $360-370{ }^{\circ} \mathrm{C}$ and $\sim 1.5 \mathrm{GPa}$, and this metamorphic condition remarkably represents a regional isograd for this process in Alpine Corsica. Episodic infiltration of external fluids at HP/LT is indicated by compositional oscillatory zoning in several HP minerals, such as garnet, e.g. Ca-rich garnet overgrowing $\mathrm{Mn}$ bellshaped Alpine HP garnet (see fig. 4a in Martin et al., 2011a), or complex compositional zoning in lawsonite and clinopyroxene $(\mathrm{Cr}$ and $\mathrm{Na}$, respectively, this study). Similar $\mathrm{Cr}$ oscillatory zoning in lawsonite is described for the lawsonitite in Guatemala, and is interpreted as the result of episodic $\mathrm{Cr}$-rich fluid influx (Tsujimori et al., 2006b; Tsujimori \& Ernst, 2014). Data provided in this study also suggest that lawsonite metasomatites formed during prograde metamorphism rather than during retrogression. The main indication for that is given by similarities in lawsonite zoning in both blueschist and eclogite facies samples (Law1-3), followed by successive rims (Law4 + Cr zoning), which are found only in eclogite facies samples. Noticeably, if in some samples traces of both blueschist and eclogite facies lawsonite metasomatism occur, in other samples, textural and petrological evidence indicates that the main metasomatic pulse occurred at eclogite facies conditions (see sample COE5 in Martin et al., 2011a). This feature probably indicates that lawsonite metasomatites formed continuously under increasing metamorphic conditions and that they locally recorded only part of the entire fluid-rock interaction history, possibly controlled by lithological (i.e. dehydration reactions) and structural (i.e. fluid pathways) constraints, or reaction overstepping.

\section{Lawsonite metasomatism and element redistribution in subduction zones}

The interaction between fluid circulating at HP and the surrounding lithologies may result in significant element redistribution (John et al., 2008; Spandler \& Pirard, 2013). Lawsonite metasomatites offer a window on the nature and composition of these fluids and the transported elements. Moreover, the occurrence of these rocks in tectonic units affected by 

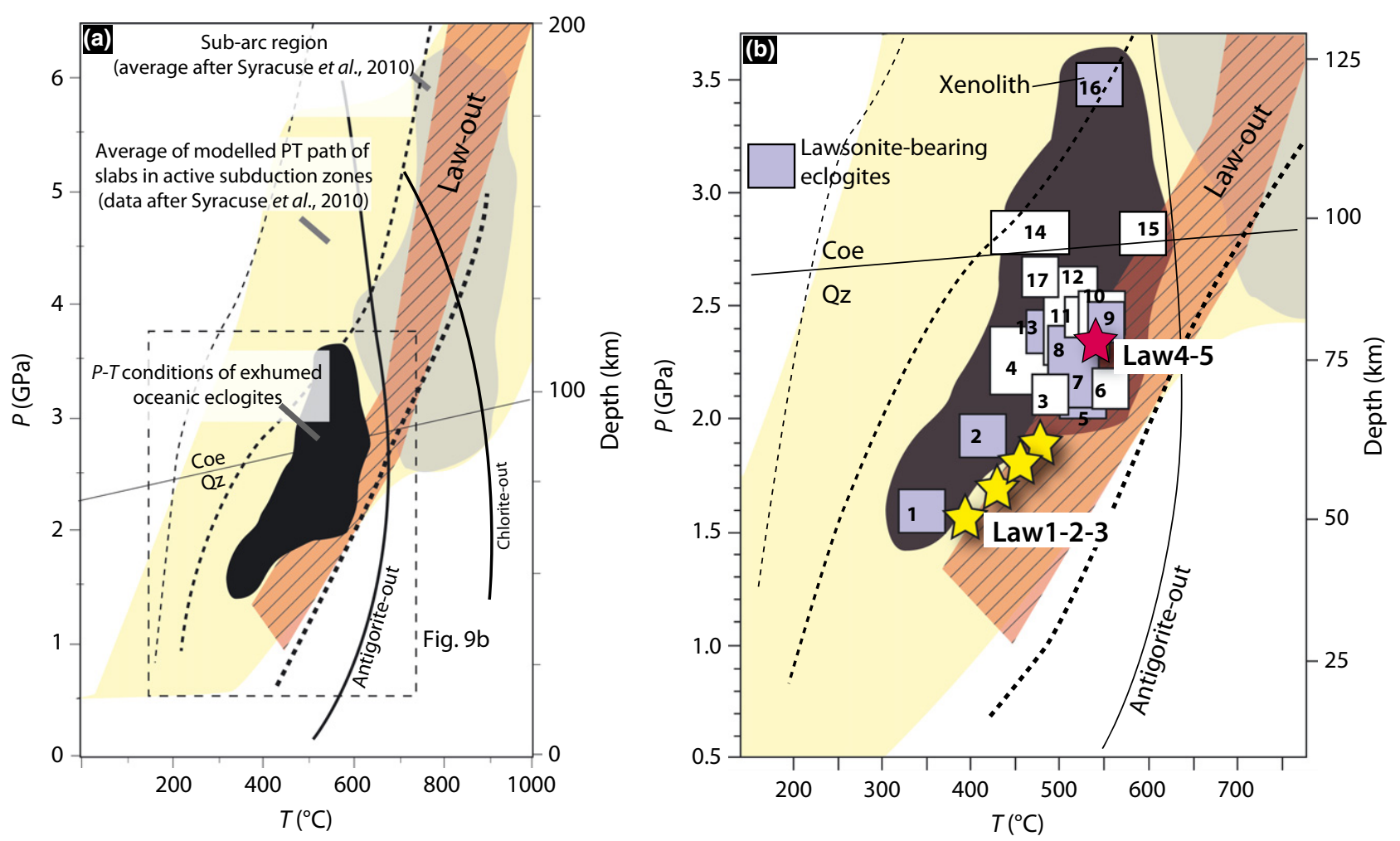

Fig. 9. $P-T$ diagram (a) and close up (b) showing the lawsonite stability field compared with the calculated $P-T$ paths of active subduction zones and the calculated $P-T$ conditions of slabs beneath volcanic arcs (averages after Syracuse et al., 2010). The lawsonite-out zone (dashed field) defined after Poli \& Schmidt (1997), Pawley (1994) and Okamoto \& Maruyama (1999) in the basaltic and CASH systems. Stability field of antigorite (Ulmer \& Trommsdorff, 1995) and chlorite (Pawley, 2003) are also shown. Calculated $P-T$ path for cold (thin dashed line), intermediate (intermediate dashed line) and hot (thick dashed line) subduction zones are shown (from van Keken et al., 2011). The dark field represents the average of estimated $P-T$ conditions of exhumed HP LT oceanic eclogites [see (b) for details]. Note that most exhumed eclogites equilibrated in the lawsonite stability field, but only a few of them preserved lawsonite during exhumation (see also Tsujimori et al., 2006a). In (b), stars refer to the estimated $P-T$ conditions of the Corsican lawsonite metasomatites. 1: Dominican Republic, Zack et al. (2004); 2: Ward Creek, California, Tsujimori et al. (2006b); 3, 9: Motagua, Endo et al. (2011); 4: Qilian, Zhang et al. (2007); 5: Indonesia, Parkinson et al. (1998); 6: Ecuador, Gabriele et al. (2003); 7: Corsica, Vitale Brovarone et al. (2011a); 8: Turkey, Davis \& Whitney (2006, 2008); 10: Zermatt, Angiboust et al. (2009); 11: New Caledonia, Fitzherbert et al. (2005); Vitale Brovarone \& Agard (2013); 12: Viso, Angiboust et al. (2011); Groppo \& Castelli (2010); 13: British Columbia, Ghent et al. (2009); 14: Tianshan, Lü \& Zhang (2012); 15: Zermatt, Groppo et al. (2009); 16: Colorado Plateau, Usui (2006); 17: Motagua, Tsujimori et al. (2006b).

various metamorphic grades allows evaluation of the evolution of the fluid phase during subduction, such as its composition, pathways and interaction with the surrounding rocks. The geochemical patterns of the studied samples show that during lawsonite metasomatism, the rock experienced deep chemical modification bearing important implications for the redistribution of elements at HP conditions. In both units and independently from the protolith (metapelites, gneiss), rocks progressively transform towards basic/ultrabasic compositions $\left(\mathrm{SiO}_{2}<45 \%\right)$, approaching the composition of pure lawsonite, i.e. CASH system (Fig. 8). The characteristic patterns of lawsonite metasomatism are depicted by rocks displaying different degrees of metasomatism, and include variation in whole-rock compositions, modal amounts and progressive chemical variation of precursor mineral phases (e.g. chlorite $X_{\mathrm{Mg}}$ and phengite
Si content increasing together with lawsonite vol.\%). The Ca enrichment is the most remarkable imprint of this process, and exists in other types of HP metasomatism (e.g. Beinlich et al., 2010; Ferrando et al., 2010). Sr, $\mathrm{Al}$ and $\mathrm{Mg}$ enrichment is equally strong, along with $\mathrm{Fe}, \mathrm{K}$ and $\mathrm{Na}$ depletion. These major element patterns are common in both blueschist facies samples and eclogite facies samples (Table 1, see also Martin et al., 2011a).

In addition, we show the selective enrichment in most trace elements (REE, LILE, HFSE such as Sr, $\mathrm{Th}, \mathrm{Pb}, \mathrm{Y}, \mathrm{Nb}, \mathrm{Ta}$ ), except for univalent LILE, together with episodic oscillatory zoning in elements such as $\mathrm{Cr}$ and $\mathrm{Na}$ that are rare or absent in the precursor rocks. Although such trends for trace elements are common to all studied samples, they are not related to lawsonite precipitation alone. REE and $\mathrm{Sr}$ mostly concentrate in lawsonite, whereas HFSE, 


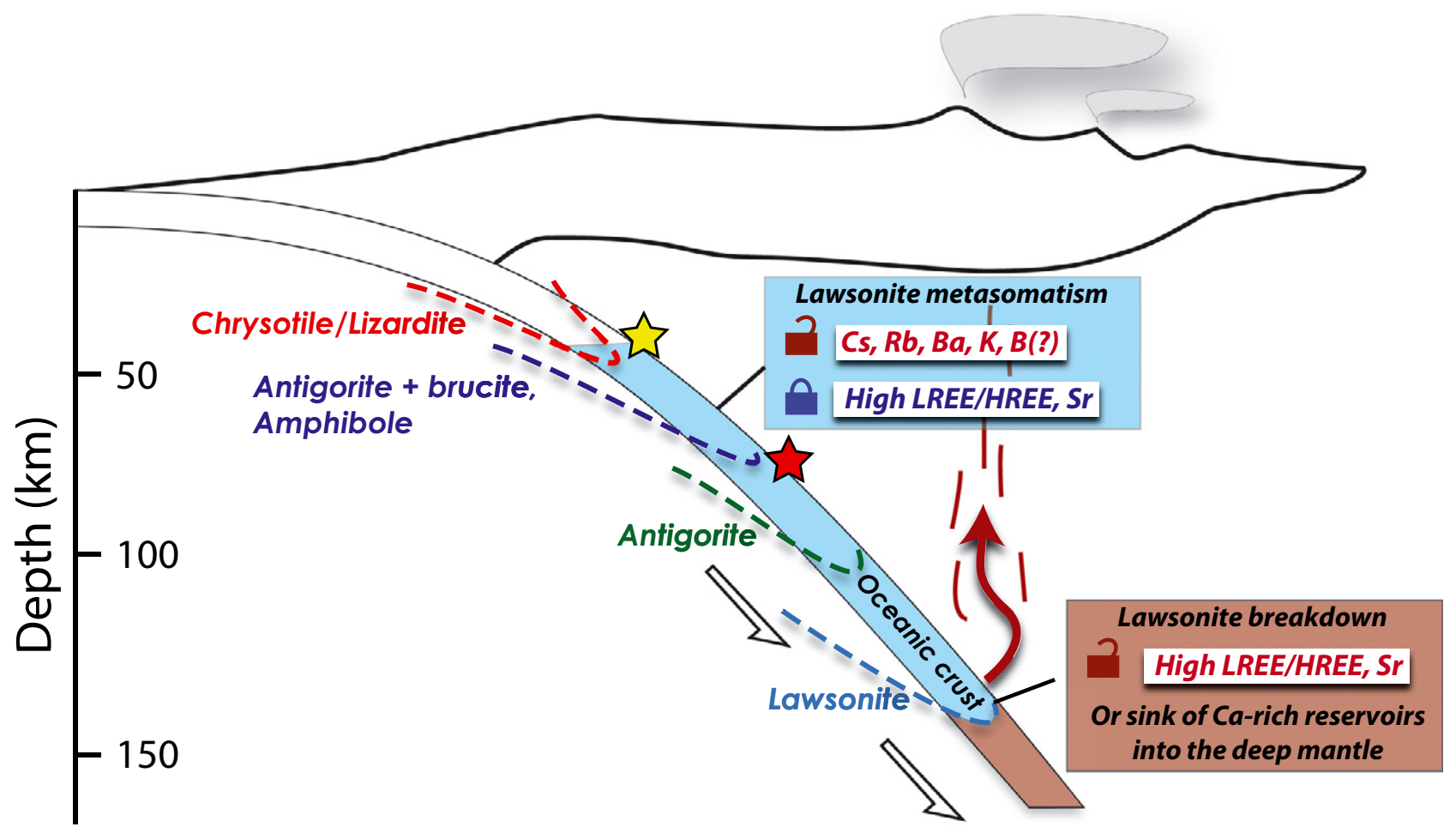

Fig. 10. Schematic representation of the relationships between metamorphic reactions and geochemical patterns in lawsonitites. The light and dark stars refer to the minimum and maximum conditions of lawsonite metasomatism found in Corsica, respectively, which also match the $P-T$ conditions at which significant serpentinite-derived fluid influx (e.g. Cr, HREE and high U/Th) occurs respectively. Formation of lawsonite metasomatites results in loss of elements such as $\mathrm{K}, \mathrm{Rb}, \mathrm{Ba}$, Cs and possibly $\mathrm{B}$ (see Discussion), and in the reincorporation of mainly high LREE/HREE, Sr and Eu from the fluid phase. The breakdown of lawsonite-rich hybrid rocks may result in significant fluxes of these elements to the mantle wedge or sink of Ca-rich reservoirs into the deep mantle.

which also increase in the whole rock, are mainly hosted in titanite $(\mathrm{Nb}, \mathrm{Ta}, \mathrm{Ti})$ and zircon $(\mathrm{Zr})$, which are also found in lawsonite metasomatites. Y shows a sudden increase as soon as lawsonite begins to form in the rock (i.e. partially replaced samples). This suggests that $\mathrm{Y}$ is primarily controlled by lawsonite, together with titanite (see also Spandler et al., 2003 for similar conclusion). Sodium has a complex behaviour as it decreases during the first stages of metasomatism from blueschist facies conditions, but it locally re-enters the system after major $\mathrm{Ca}-\mathrm{Mg}$ dominated metasomatism in eclogite facies conditions (e.g. late omphacite in diopside-dominated rocks). This feature suggests the occurrence of multiple stages of metasomatism, possibly controlled by changing $P-T$ conditions, successive dehydration reactions or variations of redox state.

Hacker (2008) discussed the role of epidosites formed during seafloor alteration as a suitable composition for anomalously high lawsonite amount at HP conditions. However, the geological implications of the two processes are different. Lawsonite metasomatism forms during subduction, and its geochemical patterns attest for the reincorporation of trace elements from the fluid phase during HP metamor- phism. Moreover, trace element mobility may be different at (sub)seafloor conditions relative to HP conditions, thus possibly resulting in different geochemical patterns. The fluid source of lawsonitites has a different origin, being the result of progressive dehydration of subducting rocks, and their interaction with the surrounding lithologies, instead of hydration of oceanic crust or seafloor hydrothermal circulations. The possible compositional contrasts between lawsonitites and epidosites would deserve further study.

As in other HP hydrated 'hybrid' rocks formed by metasomatism at HP conditions (cf. discussion in Spandler et al., 2008), lawsonite metasomatites may retain these high trace element contents to great depth. This feature can thus favour more efficient trace element redistribution at great depth during lawsonite breakdown compared with other dehydration reactions. However, compared with the other known hydrated hybrid rocks (e.g. chlorite-talc rocks, Spandler et al., 2008; Marschall \& Schumacher, 2012), lawsonitites contain overall much higher trace element concentrations (especially $\mathrm{Th} \mathrm{U}, \mathrm{Sr}, \mathrm{Pb}$ ) and are stable to greater depth where partial melting may occur in cold and intermediate subduction zones (Fig. 9). 


\section{Lawsonite compositional zoning and geochemical patterns}

Lawsonite formed during fluid-rock interactions in the studied samples displays strong compositional zoning. In samples ranging from blueschist to eclogite facies conditions, four main compositional zones were identified (Law1-4), together with local compositional signatures (e.g. Ti- or Cr-rich lawsonite), which all provide important insight into the development of lawsonite metasomatism. The most remarkable ones are discussed in the following.

(i) The high trace element concentration in Law 1 compared with the other generations. Hourglass textures associated with compositional zones Law1-3 suggest fast growth mechanism (Wass, 1973; Ueno, 1999) during the early stages of metasomatism at blueschist facies conditions (minimum $P-T=\sim 1.5 \mathrm{GPa}$ and $370{ }^{\circ} \mathrm{C}$ ). Therefore, they must be seen as a single step of lawsonite growth. Law1, however, displays a particular textural position in the core of the hourglass. Moreover, it incorporated much greater amounts of REE compared with Law2 or Law3 (LREE up to 9000 times chondrite). Law1, Law2 and Law3 have very similar REE patterns. In contrast, PM-normalized trace element patterns exhibit notable differences (see below), indicating a heterogeneous distribution in the three lawsonite types. Therefore, although microtextures suggest their contemporaneous growth, the above-mentioned trends may indicate slightly different mechanisms of growth from those of standard hourglass structures. The transition from Law3 to Law4 is characterized by oscillatory or more complex zoning, and probably represents successive stages of growth with time or varying $P-T$ conditions. They also show different REE patterns, characterized by a weaker fractionation of the HREE relative to the MREE. This is also suggested by the distinctive trends formed by the various types of lawsonite (e.g. $\mathrm{Pb} / \mathrm{Ce} v s . \mathrm{Sm} / \mathrm{Yb}$ and $\mathrm{Sr} / \mathrm{Ce} v s . \mathrm{U} /$ $\mathrm{Th})$, reflecting various fractionation processes of $\mathrm{Pb}, \mathrm{Sr}$ relative to REE and U-Th (Fig. 6e,f).

(ii) The contrasting Eu anomaly in lawsonite between blueschist and eclogite facies samples. Martin et al. (2011a) interpreted the negative Eu anomaly of lawsonite core regions as an indication of formation during the prograde path in the presence of plagioclase prior to metasomatism. However, although the blueschist facies metasomatic lawsonite studied in this work displays a distinct negative Eu anomaly, it formed (i) from protoliths that never contained plagioclase, i.e. metapelites lacking $\mathrm{Ca}$ and $\mathrm{Na}$, and (ii) at $P-T$ conditions at which albite is no longer stable $\left(370^{\circ} \mathrm{C}, 1.5 \mathrm{GPa}\right)$. On the contrary, preliminary trace element analyses on phengite show that this mineral was possibly the main host of Eu in the rock prior to, or even during, the early stage of metasomatic lawsonite precipitation. In blueschist facies samples, a progressive decrease of the Eu anomaly from Law1-2 to Law3 and finally to the small lawsonite cluster (Fig. 6a,c) may thereby support the observed progressive consumption of phengite during lawsonite growth. Moreover, the bulk rock Eu content progressively increases during the continuous enrichment of lawsonite in the rock from a distinct negative anomaly in the pristine metapelite to very weak anomaly in strongly replaced samples (Fig. 5a). This suggests that the increase of Eu in lawsonite is possibly due to $\mathrm{Eu}$ infiltration by external fluids. This feature indicates that, despite the negative Eu anomaly that is characteristic of the blueschist facies samples, the Eu anomaly may relate not only to $P-T$ conditions (e.g. plagioclase stability, Martin et al., 2011a) but also to the degree of consumption of precursor minerals (e.g. phengite) and infiltration of Eu-rich fluids.

(iii) The progressive enrichment in Sr from Law1 to Law4 in agreement with the $\mathrm{Sr}$ whole-rock variation with increasing lawsonite vol. \% is symptomatic of the massive addition of $\mathrm{Sr}$ in the system, and this clearly correlates with the very high $\mathrm{Ca}$ enrichment. Similar patterns are observed for $\mathrm{Pb}$.

(iv) The enrichment of HREE/MREE ratios in the more external lawsonite rims relative to the cores in both the blueschist (Law3) and eclogite (darker Law4) zones. This feature can be due either to the consumption of HREE-rich phases (e.g. garnet or pumpellyite, Martin et al., 2014) through changing metamorphic conditions, or it may signal a change in the nature of the fluid source, or be a consequence of all these processes. The occurrence of atoll garnet in some eclogitic lawsonite metasomatites (Martin et al., 2011a) supports the first hypothesis. However, in the studied samples, garnet does not occur, especially in blueschist facies samples, and probably indicates that HREE were available from the infiltrating fluids. As a further confirmation, in strongly metasomatized samples from both units, whole-rock HREE increase, indicating incoming fluids bearing high HREE/MREE ratios. The occurrence of these trends in the outermost lawsonite rims in both blueschist and eclogite facies samples indicates a lack of dependence on increasing $P-T$ conditions, and possibly suggests the effect of geochemical countertrends during retrograde re-equilibration. This hypothesis requires further study.

(v) The progressive fractionation of $\mathrm{Zr}$ and $\mathrm{Th}$ relative to Hf and $\mathrm{U}$ from Law1 to Law4 (Fig. 6b, d), which contrasts with the whole-rock progressive gain in both elements during metasomatism (Fig. 5b). This feature suggests the formation of metasomatic zircon, as reported by Rubatto \& 
Hermann (2003) in the HP units of the Western Alps and is supported by the occurrence of zircon in veins in sample OF3551.

(vi) The $\mathrm{Fe}$, $\mathrm{Ti}$ and $\mathrm{Cr}$ zoning. Ferric iron in lawsonite is classically believed to increase with metamorphic grade (Maruyama \& Liou, 1988), and this is confirmed by our study (Fig. 6). The occurrence of $\mathrm{Cr}$ oscillatory zoning in lawsonite has also been reported in other HP/LT rocks (e.g. Sherlock \& Okay, 1999; Davis \& Whitney, 2006). In our sample, Cr-rich lawsonite only occurs in HP veins. This feature, together with the lack of Cr-bearing phases in the studied host rock samples, probably indicates that $\mathrm{Cr}$ infiltrated from external fluids through highly channelized pathways (cf. also Spandler et al., 2011; Tsujimori \& Ernst, 2014). High Ti-Al substitution in lawsonite is not common, and this is probably the first occurrence of such a high Ti content in lawsonite. This feature will deserve further mineralogical study. In our rocks, Ti increases with increasing metasomatism, but at low $P-T$ conditions (Fig. 7), along with $\mathrm{Nb}$ enrichment in lawsonite, which typically concentrates in Ti-bearing phases (Zack et al., 2002). This feature suggests that $\mathrm{Ti}$ zoning in lawsonite may be due to episodic destabilization of Ti-bearing phases in the surrounding rocks. The early destabilization of rutile in metapelites in favour of titanite formation during metasomatism (Fig. 3a-c), together with the occurrence of Ti-rich lawsonite only at low $P-T$ conditions (Fig. 6), supports this hypothesis, and also suggests a possible $\mathrm{Ti}$ repartition between titanite and lawsonite during rutile breakdown. Titanite formation may also account for strong HFSE fractionation in lawsonite compared with the whole rock (Fig. 6b,d). In the studied samples, we therefore observe a progressive $\mathrm{Ti} /$ $\mathrm{Fe} / \mathrm{Cr}-\mathrm{Al}$ substitution with increasing metamorphic grade (Fig. 7). This feature can derive either from a variation of the structural properties of lawsonite under rising $P-T$, or from the mineralogical evolution of the surrounding lithologies during metamorphism or both. There has been little study of the substitution of $\mathrm{Fe}, \mathrm{Cr}$ and $\mathrm{Ti}$ in lawsonite, and, especially for $\mathrm{Ti}$, more work is encouraged for possible thermobarometric applications.

\section{Fluid sources}

Fluid generated by successive dehydration reactions in different lithologies may favour chemical interaction along lithological boundaries, especially where chemical contrast is strong (e.g. Bach et al., 2013; Galvez et al., 2013). The geochemical patterns of lawsonite metasomatites permit discussion of the possible lithologies involved in this process at HP conditions.
Calcium enrichment characterizes the entire evolution of lawsonite metasomatism, but does not provide a unique clue about the fluid source. Possible sources of $\mathrm{Ca}$ exist in all involved lithologies, such as metabasics, serpentinite and meta-sedimentary rocks. If lawsonite metasomatism is compared with rodingitization, it is important to notice that, despite the evidence that the fluid was Ca-rich (see Mass change during metasomatism), lawsonite metasomatism was possibly enhanced not only by the abundance of $\mathrm{Ca}$ in the fluid but also by the low silica activity (note the strong decrease in $\mathrm{Si}$ in lawsonite metasomatites) in the rock resulting from fluid-rock interaction (see Bach \& Klein, 2009; Bach et al., 2013 for rodingite formation). Both $\mathrm{Ca}$ enrichment and decreasing $\mathrm{Si}$ activity are therefore proposed as motors for lawsonite metasomatism. Strontium progressively increases in lawsonite, as well as in the whole rock. Again different sources can be envisaged, such as plagioclaserich lithologies (i.e. mafic rocks), carbonate-rich meta-sedimentary rocks and serpentinite. Recent investigations into the geochemical evolution of serpentinites under increasing $P-T$ demonstrated that $\mathrm{Sr}$ is mobilized from serpentinites from about 360 to $\sim 390{ }^{\circ} \mathrm{C}$ due to lizardite/chrysotile breakdown in favour of antigorite (Lafay et al., 2013). This temperature range $\left(360-390{ }^{\circ} \mathrm{C}\right)$ is consistent with the regional isograd for lawsonite metasomatism in Alpine Corsica, corresponding to $\sim 370{ }^{\circ} \mathrm{C}$. Moreover, the marked U/Th-positive fractionation, $\mathrm{Sr}$ and $\mathrm{Pb}$ enrichment over $\mathrm{Ce}$, and the higher HREE abundances in Law3 and in particular in Law4 are typical signatures of serpentinites and altered oceanic lithosphere (Staudigel et al., 1996; Godard et al., 2008).

Chromium influx characterizing some eclogite facies samples provides more robust insights into fluid sources. Chromium-rich samples also have high $\mathrm{Ni}$, which have been shown to be tracers of serpentinites-derived fluids at HP conditions (e.g. Spandler et al., 2011). The availability of serpentinite-derived fluid under eclogite facies conditions matches with the $P-T$ conditions required for brucite breakdown $\left(\sim 500{ }^{\circ} \mathrm{C}\right.$ at $2 \mathrm{GPa}$, e.g. Evans et al., 1976; Scambelluri et al., 1991), which in turn matches the regional $P-T$ conditions of prograde eclogite facies metamorphism in Alpine Corsica (Vitale Brovarone et al., 2011a, 2013). All the above features suggest that serpentinites probably represent a major source of fluids (and elements) for lawsonite metasomatism under various $P-T$ conditions. These fluids then reacted along lithological boundaries involving different lithologies, e.g. metabasites and meta-sedimentary rocks, which possibly contributed to the characteristic geochemical signatures of lawsonitites (e.g. Ca). Notably, lawsonite-rich products commonly formed on protoliths poor in $\mathrm{Ca}$ prior to metasomatism (e.g. metapelites), indicating a complex element redistribution between a fluid phase and one or more rock types. 
However, lawsonite metasomatites were also found in the presence of mafic rocks, suggesting alternatively (i) distinct and locally derived fluid sources, (ii) serpentinite-derived fluid and large-scale fluid flows or (iii) both processes. The strong similitude of trace element patterns for whole rock and lawsonite zoning in similar microstructural context in both blueschist and eclogite facies samples (Fig. 6) suggests that diverse fluid sources are unlikely. It could be argued that this strong similitude is due to the lattice structure of lawsonite relative to partition coefficient at different $P-T$ conditions. However, given the rather constant composition of lawsonite at different $P-T$ and the wide range of trace elements that it contains, this appears unlikely. Furthermore, the various generations of lawsonite have significantly different REE and LILE patterns. This suggests that the composition of the fluid is similar at the beginning of lawsonite metasomatism (Law1-2) and at the later stages of lawsonite formation (Law3 $\approx$ Law4), and points to serpentinite as the most probable fluid source. In any case, it is worth noticing that water incorporated in lawsonitites may derive from external fluid sources (e.g. serpentinites) and from in situ consumption of hydrous phases during metasomatism (e.g. phengite).

If serpentinites were considered as the main fluid and elemental source, the data provided here indicate the occurrence of large-scale (tens to hundreds of metres to justify the development of lawsonite rinds in the absence of serpentinite) fluid flows at HP. This conclusion somewhat differs from previous studies that proposed local or internally derived fluids in Alpine HP complexes (e.g. Corsica: Miller et al., 2001; Western Alps: Philippot \& Silverstone, 1991; Busigny et al., 2003). Large-scale fluid flow at HP conditions has been shown to be highly channelized (e.g. Miller et al., 2003; Zack \& John, 2007). The occurrence of lawsonite metasomatites along lithological boundaries suggests the localization of fluid pathways along compositional/rheological discontinuities, and supports this hypothesis. However, lawsonite rinds also occur around isolated mafic blocks in meta-sedimentary rocks, suggesting large-scale networks of fluid pathways (cf. model by Miller et al., 2003).

\section{Lawsonite metasomatism and magmatism}

As shown in the previous sections, lawsonite metasomatism induces a progressive chemical shift towards the CASH system. In this chemical system, the stability of lawsonite is enhanced, allowing it to be stable at higher temperature relative to the basaltic system (Poli \& Schmidt, 1995; Martin et al., 2014). This feature suggests that the stability of lawsonitites may extend to deeper conditions, and reach sub-arc conditions. The breakdown of lawsonite from metasomatites may thus contribute to the genesis of arc magmas and their chemical signature, by releasing water and as a reservoir of trace elements. The close- ness between partial melting reactions in sediments or oceanic crust, and lawsonite breakdown reactions in the CASH system between 3.5 and 4.5 GPa (Martin et al., 2014) also suggest that, when present, lawsonite metasomatites may play a role in the partial melting of the surrounding lithologies. This mechanism may be particularly efficient in chaotic structures that may form along the plate interface, also referred to as subduction mélanges, where lawsonitites have been shown to form (Tsujimori \& Ernst, 2014).

Fluid-rock interaction and metasomatism are powerful mechanisms to transfer elements at HP conditions (e.g. Breeding et al., 2004; Zack \& John, 2007; Spandler et al., 2008; Spandler \& Pirard, 2013). These processes and the resulting metasomatic rocks, or 'hybrid' rocks (e.g. Spandler et al., 2008), have been shown to be a key element for the three-component mixing model (fluid-mafic-meta-sedimentary) proposed for the genesis of the particular geochemical fingerprints of arc magmas, which are characterized by high LILE, high LREE/HREE and low HFSE (e.g. McCulloch \& Gamble, 1991; Marschall \& Schumacher, 2012 and references therein). Lawsonite metasomatism favours the formation of rocks with high LREE/REE ratios and concentration of high valence LILE (especially Sr, Figs 5 \& 6e,f). However, the proportion of these elements transferred to the fluid $v s$. minerals such as allanite or epidote after lawsonite breakdown depends on the partitioning of the trace elements between the fluid phase and these minerals, which is still poorly understood (see Martin et al., 2014 for a discussion). The process of lawsonite metasomatism also results in a significant loss of univalent LILE ( $\mathrm{Cs}, \mathrm{Ba}, \mathrm{Rb}$ and $\mathrm{K})$. A protracted metasomatism at HP conditions, possibly enhanced by the full antigorite breakdown, may represent a source of these elements in the fore to sub-arc mantle and then in arc magmas. The high HFSE in lawsonitite are mainly hosted in titanite, which probably behaves as a residual phase during partial melting (McCulloch \& Gamble, 1991).

Lawsonite metasomatism may also contribute to the formation of Ca-rich reservoirs in the deep mantle. It has been proposed that these chemical heterogeneities in the deep mantle may explain some of the geochemical characteristics of magmas originated from deep mantle sources, such as Ocean Island Basalt (Brenker et al., 2005). Ca-rich deep mantle inclusions studied by these authors show enrichment in $\mathrm{Sr}, \mathrm{Y}, \mathrm{Zr}, \mathrm{U}$ and $\mathrm{Th}$, which match in part the geochemical enrichment in lawsonitites ( $\mathrm{Sr}, \mathrm{Y}, \mathrm{Zr}, \mathrm{Th}$ ). Therefore, lawsonite metasomatism involves major and trace element redistributions that are consistent with some of the geochemical patterns of arc and deep magmas, and may be therefore contribute, at least in part, to their genesis.

Boron isotopes are a marker of fluid-mediated mass transfer during subduction (Peacock \& Hervig, 
1999; Scambelluri \& Tonarini, 2012). Some authors considered lawsonite (and chlorite) as a significant B reservoir (e.g. Domanik et al., 1993; Bebout et al., 2007), whereas other authors questioned its relevance as a B host (Marschall et al., 2006). Our analyses of $\mathrm{B}$ in lawsonite show maximum concentrations in the range of 4-7 $\mu \mathrm{g} \mathrm{g}^{-1}$, which are not negligible if possible B surface contaminations are excluded (e.g. Marschall \& Ludwig, 2004). Although our B data have to be considered as preliminary, the generally low B concentration in titanite $\left(<1 \mu \mathrm{g} \mathrm{g}^{-1}\right)$ and in the outermost lawsonite rims relative to the cores may suggest limited surface contaminations, and permit a preliminary interpretation to be made. The drastic consumption of phengite (main B host in HP rocks, Marschall et al., 2006) in lawsonite-chlorite fels may possibly result in either (i) partial B loss during metasomatism and generation of B-rich fluids or (ii) the incorporation of still relatively high $\mathrm{B}$ amount in lawsonite and chlorite (hypothesis to be tested with additional analyses). Our data show that the progressive growth of lawsonite (Law1-4) is accompanied by a decrease in the $\mathrm{B}$ content, possibly supporting the first hypothesis. Precipitation and destabilization of lawsonite metasomatites may therefore possibly participate in the enrichments in ${ }^{11} \mathrm{~B}$ of slab-derived fluids.

\section{CONCLUSIONS}

This work provides a structural, microstructural and geochemical overview of lawsonite metasomatism in Alpine Corsica. These rocks started to form at prearc depths, from $370{ }^{\circ} \mathrm{C} / 1.5 \mathrm{GPa}$, to at least $550{ }^{\circ} \mathrm{C} / 2.3 \mathrm{GPa}$, and were able to incorporate a large amount of trace elements circulating at HP conditions. This metasomatism resulted from the interaction between serpentinite-derived fluids and other lithologies, such as metamafic and/or metasedimentary rocks. The characteristic signature of lawsonite metasomatite matches in part with that of volcanic arc products, e.g. enrichment of $\mathrm{Sr}$ and $\mathrm{Pb}$ over REE and high LREE/HREE. The subsequent destabilization of these rocks, which may occur at sub-arc depth in subduction zones characterized by intermediate geothermal gradients, may possibly represent a fluid and elemental source for magmas or geochemical heterogeneities in the deep mantle. In cold subduction zones, these rocks may otherwise represent a major host of $\mathrm{Ca}$, trace elements and water to great depth, with important implications for geochemical cycling at subduction zones and back-arc settings.

\section{ACKNOWLEDGEMENTS}

We thank D. Whitney for editorial handling; B. Hacker and T. Tsujimori for constructive reviews that helped in improving the quality of the paper. R.
Compagnoni and $\mathrm{H}$. Marschall are thanked for constructive discussion. The first author was supported by French state funds managed by the ANR within the Investissements d'Avenir programme under reference ANR-11-IDEX-0004-02, and more specifically within the framework of the Cluster of Excellence MATISSE. This work has also benefited from research funds from CNRS - INSU (Syster program). Scanning Electron Microscope (SEM) facility of the Institut de Minéralogie et de Physique des Milieux Condensés is supported by Région Ile de France grant SESAME $2006 \mathrm{~N}^{\circ} \mathrm{I}-07-593 / \mathrm{R}$, INSU-CNRS, INP-CNRS, University Pierre et Marie Curie - Paris 6, and by the French National Research Agency (ANR) grant no. ANR-07-BLAN-0124-01.

\section{REFERENCES}

Abers, G.A., Nakajima, J., van Keken, P.E., Kita, S. \& Hacker, B.R., 2013. Thermal-petrological controls on the location of earthquakes within subducting plates. Earth and Planetary Science Letters, 369-370, 178-187. doi:10.1016/j. eps1.2013.03.022

Agard, P., Yamato, P., Jolivet, L. \& Burov, E., 2009. Exhumation of oceanic blueschists and eclogites in subduction zones: timing and mechanisms. Earth Science Reviews, 92, 53-79. doi:10.1016/j.earscirev.2008.11.002

Angiboust, S., Agard, P., Jolivet, L. \& Beyssac, O., 2009. The Zermatt-Saas ophiolite: the largest $(60-\mathrm{km}$ wide) and deepest $($ c. $70-80 \mathrm{~km})$ continuous slice of oceanic lithosphere detached from a subduction zone? Terra Nova, 21, 171-180. doi:10.1111/j.1365-3121.2009.00870.x

Angiboust, S., Langdon, R., Agard, P., Waters, D. \& Chopin, C., 2011. Eclogitization of the Monviso ophiolite (W. Alps) and implications on subduction dynamics. Journal of Metamorphic Geology, 30, 37-61. doi:10.1111/j.1525-1314.2011. 00951.x

Bach, W. \& Klein, F., 2009. The petrology of seafloor rodingites: insights from geochemical reaction path modeling. Lithos, 112, 103-117. doi:10.1016/j.lithos.2008.10.022

Bach, W., Jöns, N. \& Klein, F. 2013. Metasomatism within the ocean crust. In: Metasomatism and the Chemical Transformation of Rock (eds Harlov, D.E. \& Austrheim, H.), pp. 253-288. Springer, Berlin/Heidelberg. doi:10.1007/ 978-3-642-28394-9_8

Bebout, G.E., Bebout, A.E. \& Graham, C.M., 2007. Cycling of $\mathrm{B}, \mathrm{Li}$, and LILE (K, $\mathrm{Cs}, \mathrm{Rb}, \mathrm{Ba}, \mathrm{Sr}$ ) into subduction zones: SIMS evidence from micas in high-P/T metasedimentary rocks. Chemical Geology, 239, 284-304.

Beinlich, A., Klemd, R., John, T. \& Gao, J., 2010. Trace-element mobilization during Ca-metasomatism along a major fluid conduit: eclogitization of blueschist as a consequence of fluid-rock interaction. Geochimica et Cosmochimica Acta, 74, 1892-1922. doi:10.1016/j.gca.2009.12.011

Breeding, C.M., Ague, J.J. \& Bröcker, M., 2004. Fluid-metasedimentary rock interactions in subduction-zone mélange: implications for the chemical composition of arc magmas. Geology, 32, 1041. doi:10.1130/G20877.1

Brenker, F.E., Vincze, L., Vekemans, B. et al., 2005. Detection of a Ca-rich lithology in the Earth's deep (>300 km) convecting mantle. Earth and Planetary Science Letters, 236, 579-587. doi:10.1016/j.epsl.2005.05.021

Brunet, C., Monié, P., Jolivet, L. \& Cadet, J.P., 2000. Migration of compression and extension in the Tyrrhenian Sea, insights from ${ }^{40} \mathrm{Ar} /{ }^{39} \mathrm{Ar}$ ages on micas along a transect from Corsica to Tuscany. Tectonophysics, 321, 127-155. 
Busigny, V., Cartigny, P., Philippot, P., Ader, M. \& Javoy, M., 2003. Massive recycling of nitrogen and other fluid-mobile elements $(\mathrm{K}, \mathrm{Rb}, \mathrm{Cs}, \mathrm{H})$ in a cold slab environment: evidence from HP to UHP oceanic metasediments of the Schistes Lustrés nappe (western Alps, Europe). Earth and Planetary Science Letters, 215, 27-42. doi:10.1016 S0012-821X(03)00453-9

Carignan, J., Hild, P., Mevelle, G., Morel, J. \& Yeghicheyan, D., 2001. Routine analyses of trace elements in geological samples using flow, injection and low pressure on-line liquid chromatography coupled to ICP-MS: a study of reference materials BR, DR-N, UB-N, AN-G and GH. Geostandard Newsletter: The Journal of Geostandards and Geoanalysis, 25 (2-3), 187-198.

Caron, J.M. \& Péquignot, G., 1986. The transition between blueschists and lawsonite-bearing eclogites based on observations from Corsican metabasalts. Lithos, 19, 205-218.

Clarke, G.L., Powell, R. \& Fitzherbert, J.A., 2006. The lawsonite paradox: a comparison of field evidence and mineral equilibria modelling. Journal of Metamorphic Geology, 24, 715-725. doi:10.1111/j.1525-1314.2006.00664.x

Davis, P.B. \& Whitney, D.L., 2006. Petrogenesis of lawsonite and epidote eclogite and blueschist, Sivrihisar Massif, Turkey. Journal of Metamorphic Geology, 24, 823-849. doi:10. $1111 / \mathrm{j} .1525-1314.2006 .00671 . x$

Davis, P.B. \& Whitney, D.L., 2008. Petrogenesis and structural petrology of high-pressure metabasalt pods, Sivrihisar, Turkey. Contributions to Mineralogy and Petrology, 156, $217-$ 241. doi:10.1007/s00410-008-0282-4

Deschamps, F., Godard, M., Guillot, S. \& Hattori, K., 2013. Geochemistry of subduction zone serpentinites: a review. Lithos, 178, 96-127. doi:10.1016/j.Lithos.2013.05.019

Domanik, K.J., Hervig, R.L. \& Peacock, S.M., 1993. Beryllium and boron in subduction zone minerals: an ion microprobe study. Geochimica et Cosmochimica Acta, 57, 49975010.

Endo, S., Wallis, S.R., Tsuboi, M., Torres de Leon, R. \& Solari, L.A., 2011. Metamorphic evolution of lawsonite eclogites from the southern Motagua fault zone, Guatemala: insights from phase equilibria and Raman spectroscopy. Journal of Metamorphic Geology, 30, 143-164. doi:10.1111/j. 1525-1314.2011.00960.x

Evans, B.W., Johannes, J., Oterdoom, W.H. \& Trommsdorff, V., 1976. Stability of crysotile and antigorite in the serpentinite multisystem. Schweizerische Mineralogische und Petrografiche Mitteilungen, 56, 79-93.

Ferrando, S., Frezzotti, M.-L., Orione, P., Conte, R.C. \& Compagnoni, R., 2010. Late-Alpine rodingitization in the Bellecombe meta-ophiolites (Aosta Valley, Italian Western Alps): evidence from mineral assemblages and serpentinization-derived $\mathrm{H}_{2} \mathrm{O}$-bearing brine. International Geology Review, 52, 1220-1243. doi:10.1080/00206810903557761

Fitzherbert, J.A., Clarke, G.L. \& Powell, R., 2005. Preferential retrogression of high-P metasediments and the preservation of blueschist to eclogite facies metabasite during exhumation, Diahot terrane, NE New Caledonia. Lithos, 83, 67-96.

Gabriele, P., Ballèvre, M., Jaillard, E. \& Hernandez, J., 2003. Garnet-chloritoid-kyanite metapelites from the Raspas Complex (SW Ecuador): a key eclogite-facies assemblage. European Journal of Mineralogy, 15, 977-989. doi:10.1127 0935-1221/2003/0015-0977

Galvez, M.E., Martinez, I., Beyssac, O., Benzerara, K., Agrinier, P. \& Assayag, N., 2013. Metasomatism and graphite formation at a lithological interface in Malaspina (Alpine Corsica, France). Contributions to Mineralogy and Petrology, 166, 1687-1708. doi:10.1007/s00410-013-0949-3

Ghent, E., Tinkham, D. \& Marr, R., 2009. Lawsonite eclogites from the Pinchi Lake area, British Columbia-new P-T estimates and interpretation. Lithos, 109, 248-253. doi:10.1016/j. lithos.2008.06.018

Godard, M., Lagabrielle, Y. \& Alard, O., 2008. Geochemistry of the highly depleted peridotites drilled at ODP Sites 1272 and 1274 (Fifteen-Twenty Fracture Zone, Mid-Atlantic Ridge): implications for mantle dynamics beneath a slow spreading ridge. Earth and Planetary Science Letters, 267, 410-425.

Grant, J.A., 2005. Isocon analysis: a brief review of the method and applications. Physics and Chemistry of the Earth, Parts $A / B / C, 30,997-1004$. doi:10.1016/j.pce.2004.11. 003

Griffin, W.L., Powell, W.J., Pearson, N.J. \& O'Reilly, S.Y., 2008. Glitter: data reduction software for laser ablation ICP-MS. In: Laser Ablation ICP-MS in the Earth Sciences: Current Practices and Outstanding Issues (ed. Sylvester, P.), Mineralogical Association of Canada, Short Course Series, 40, 308-311.

Groppo, C. \& Castelli, D., 2010. Prograde P-T evolution of a lawsonite eclogite from the Monviso Meta-ophiolite (Western Alps): dehydration and redox reactions during subduction of oceanic FeTi-oxide Gabbro. Journal of Petrology, 51, 2489-2514. doi:10.1093/petrology/egq065

Groppo, C., Beltrando, M. \& Compagnoni, R., 2009. The $P-T$ path of the ultra-high pressure Lago Di Cignana and adjoining high-pressure meta-ophiolitic units: insights into the evolution of the subducting Tethyan slab. Journal of Metamorphic Geology, 27, 207-231. doi:10.1111/j.1525-1314. 2009.00814.x

Hacker, B.R., 2008. $\mathrm{H}_{2} \mathrm{O}$ subduction beyond arcs. Geochemistry, Geophysics, Geosystems, 9, Q03001. doi:10.1029/ 2007GC001707

John, T., Klemd, R., Gao, J. \& Garbe-Schönberg, C.D., 2008. Trace-element mobilization in slabs due to non steady-state fluid-rock interaction: constraints from an eclogite-facies transport vein in blueschist (Tianshan, China). Lithos, 103, 1-24. doi:10.1016/j.lithos.2007.09.005

Jolivet, L., Dubois, R., Fournier, M., Goffé, B., Michard, A. \& Jourdan, C., 1990. Ductile extension in Alpine Corsica. Geology, 18, 1007-1010.

van Keken, P.E., Hacker, B.R., Syracuse, E.M. \& Abers, G.A., 2011. Subduction factory: 4. Depth-dependent flux of $\mathrm{H} 2 \mathrm{O}$ from subducting slabs worldwide. Journal of Geophysical Research, 116, B01401. doi:10.1029/2010JB007922

Kerrick, D.M. \& Connolly, J.A.D., 2001. Metamorphic devolatilization of subducted oceanic metabasalts: implications for seismicity, arc magmatism and volatile recycling. Earth and Planetary Science Letters, 189, 19-29.

Krogh, E.J., Oh, C.W. \& Liou, J.G., 1994. Polyphase and anticlockwise P-T evolution for Franciscan eclogites and blueschists from Jenner, California, USA. Journal of Metamorphic Geology, 12, 121-134.

Lafay, R., Deschamps, F., Schwartz, S. et al., 2013. High-pressure serpentinites, a trap-and-release system controlled by metamorphic conditions: example from the Piedmont zone of the western Alps. Chemical Geology, 343, 38-54.

Lagabrielle, Y. \& Lemoine, M., 1997. Alpine, Corsican and Apennine ophiolites: the slow-spreading ridge model. Comptes Rendus de l'Académie des Sciences-Series IIA-Earth and Planetary Science, 325, 909-920.

Lahondère, D., 2006. Les schistes bleus et les éclogites à lawsonite des unités continentales et océaniques de la Corse Alpine, Vol. 240. Documents du BRGM, Orleans.

Leake, B.E., Woolley, A.R., Arps, C.E.S. et al., 1997. Nomenclature of amphiboles: report of the subcommittee on amphiboles of the International Mineralogical Association, Commission on New Minerals and Mineral Names. Canadian Mineralogist, 35, 219-246.

Longerich, H.P., Guenther, D. \& Jackson, S.E., 1996. Elemental fractionation in laser ablation inductively coupled plasma mass spectrometry. Fresenius' Journal of Analytical Chemistry, 355, 538-542.

Lü, Z. \& Zhang, L., 2012. Coesite in the eclogite and schist of the Atantayi Valley, southwestern Tianshan, China. Chinese Science Bulletin, 57, 1467-1472. doi:10.1007/ s11434-012-4979-4 
Marschall, H.R. \& Ludwig, T., 2004. The Low-Boron contest: minimising surface contamination and analysing boron concentrations at the $\mathrm{ng} / \mathrm{glevel}$ by secondary ion mass spectrometry. Mineralogy and Petrology, 81, 265-278.

Marschall, H.R. \& Schumacher, J.C., 2012. Arc magmas sourced from mélange diapirs in subduction zones. Nature Geoscience, 5, 862-867.

Marschall, H.R., Altherr, R., Ludwig, T., Kalt, A., Gméling, K. \& Kasztovszky, Z., 2006. Partitioning and budget of Li, $\mathrm{Be}$ and $\mathrm{B}$ in high-pressure metamorphic rocks. Geochimica et Cosmochimica Acta, 70, 4750-4769. doi:10.1016/j.gca.2006. 07.006

Martin, L.A.J., Rubatto, D., Vitale Brovarone, A. \& Hermann, J., 2011a. Late Eocene lawsonite-eclogite facies metasomatism of a granulite sliver associated to ophiolites in Alpine Corsica. Lithos, 125, 620-640. doi:10.1016/j.lithos. 2011.03.015

Martin, L.A.J., Wood, B.J., Turner, S. \& Rushmer, T., 2011 b. Experimental measurements of trace element partitioning between lawsonite, zoisite and fluid and their implication for the composition of arc magmas. Journal of Petrology, 52, 1049-1075. doi:10.1093/petrology/egr018

Martin , L.A.J., Hermann, J., Gauthiez-Putallaz, L., Whitney, D., Vitale-Brovarone, A. \& Evans, N., 2014. Lawsonite geochemistry and stability - implication for trace element and water cycles in subduction zones. Journal of Metamorphic Geology.

Maruyama, S. \& Liou, J.G., 1988. Petrology of Franciscan Metabasites along the Jadeite-Glaucophane type facies series, Cazadero, California. Journal of Petrology, 29, 1-37.

McCulloch, M. \& Gamble, A., 1991. Geochemical and geodynamical constraints on subduction zone magmatism. Earth and Planetary Science Letters, 102, 358-374.

Meresse, F., Lagabrielle, Y., Malavieille, J. \& Ildefonse, B., 2012. A fossil ocean-continent transition of the Mesozoic Tethys preserved in the Schistes Lustrés nappe of northern Corsica. Tectonophysics, 579, 4-16. doi:10.1016/j.tecto.2012. 06.013

Miller, J.A., Cartwright, I., Buick, I.S. \& Barnicoat, A.C., 2001. An O-isotope profile through the HP-LT Corsican ophiolite, France and its implications for fluid flow during subduction. Chemical Geology, 178, 43-69.

Miller, S.A., van der Zee, W., Olgaard, D.L. \& Connolly, J.A.D., 2003. A fluid-pressure feedback model of dehydration reactions: experiments, modelling, and application to subduction zones. Tectonophysics, 370, 241-251.

Miyazoe, T., Enami, M., Nishiyama, T. \& Mori, Y., 2012. Retrograde strontium metasomatism in serpentinite mélange of the Kurosegawa Zone in central Kyushu, Japan. Mineralogical Magazine, 76, 635-647. doi:10.1180/minmag.2012.076. 3.14

Molli, G. \& Malavieille, J., 2010. Orogenic processes and the Corsica/Apennines geodynamic evolution: insights from Taiwan. International Journal of Earth Sciences, 100, 1207-1224. doi:10.1007/s00531-010-0598-y

Morimoto, N., Fabries, J. \& Ferguson, A.K., 1988. Nomenclature of pyroxenes. American Mineralogist, 73, 1123-1133.

Okamoto, K. \& Maruyama, S., 1999. The high-pressure synthesis of lawsonite in the $\mathrm{MORB}+\mathrm{H}_{2} \mathrm{O}$ system. American Mineralogist, 84, 362-373.

Parkinson, C.D., Miyazaki, K., Wakita, K., Barber, A.J. \& Carswell, D.A., 1998. An overview and tectonic synthesis of the pre-Tertiary very-high-pressure metamorphic and associated rocks of Java, Sulawesi and Kalimantan, Indonesia. Island Arc, 7, 184-200.

Pawley, A.R., 1994. The pressure and temperature stability limits of lawsonite: implications for $\mathrm{H}_{2} \mathrm{O}$ recycling in subduction zones. Contributions to Mineralogy and Petrology, 118, 99-108.

Pawley, A., 2003. Chlorite stability in mantle peridotite: the reaction clinochlore + enstatite $=$ forsterite + pyrope $+\mathrm{H}_{2} \mathrm{O}$. Contributions to Mineralogy and Petrology, 144, 449-456.
Peacock, S.M., 1999. Seismic consequences of warm versus cool subduction metamorphism: examples from Southwest and Northeast Japan. Science, 286, 937-939. doi:10.1126/science.286.5441.937

Peacock, S.M. \& Hervig, R.L., 1999. Boron isotopic composition of subduction-zone metamorphic rocks. Chemical Geology, 160, 281-290.

Pearce, N.J.G., Perkins, W.T., Westgate, J.A. et al., 1997. A compilation of new and published major and trace element data for NIST SRL 610 and NIST SRM 612 glass reference materials. Geostandards Newsletter, 21, 115-144.

Philippot, P. \& Silverstone, J., 1991. Trace-element-rich brines in eclogitic veins: implications for fluid composition and transport during subduction. Contributions to Mineralogy and Petrology, 106, 417-430.

Poli, S. \& Schmidt, M.W., 1995. $\mathrm{H}_{2} \mathrm{O}$ transport and release in subduction zones: experimental constraints on basaltic and andesitic system. Journal of Geophysical Research, 100(B11): 22,299-22,314.

Poli, S. \& Schmidt, M.W., 1997. The high-pressure stability of hydrous phases in orogenic belts: an experimental approach on eclogite-forming processes. Tectonophysics, 273, 169-184.

Ravna, E.J.K., Andersen, B., Jolivet, L. \& De Capitani, C., 2010. Cold subduction and the formation of lawsonite eclogite - constraints from prograde evolution of eclogitized pillow lava from Corsica. Journal of Metamorphic Geology, 28, 381-395.

Rubatto, D. \& Hermann, J., 2003. Zircon formation during fluid circulation in eclogites (Monviso, Western Alps): implications for $\mathrm{Zr}$ and $\mathrm{Hf}$ budget in subduction zones. Geochimica et Cosmochimica Acta, 67, 2173-2187. doi:10.1016/ S0016-7037(02)01321-2

Scambelluri, M. \& Tonarini, S., 2012. Boron isotope evidence for shallow fluid transfer across subduction zones by serpentinized mantle. Geology, 40, 907-910.

Scambelluri, M., Piccardo, G.B., Vissers, R. \& Rampone, E., 1991. Alpine olivine- and titanian clinohumite-bearing assemblages in the Erro-Tobbio peridotite (Voltri Massif, NW Italy). Journal of Metamorphic Geology, 9, 79-91.

Sherlock, S.C. \& Okay, A.I., 1999. Oscillatory zoned chrome lawsonite in the Tav anlt Zone, northwest Turkey. Mineralogical Magazine, 63, 687-692.

Spandler, C. \& Pirard, C., 2013. Element recycling from subducting slabs to arc crust: a review. Lithos, 170-171, 208223. doi:10.1016/j.lithos.2013.02.016

Spandler, C., Hermann, J.R., Arculus, R. \& Mavrogenes, J., 2003. Redistribution of trace elements during prograde metamorphism from lawsonite blueschist to eclogite facies; implications for deep subduction-zone processes. Contributions to Mineralogy and Petrology, 146, 205-222. doi:10.1007/ s00410-003-0495-5

Spandler, C., Hermann, J., Faure, K., Mavrogenes, J.A. \& Arculus, R.J., 2008. The importance of talc and chlorite 'hybrid' rocks for volatile recycling through subduction zones; evidence from the high-pressure subduction mélange of New Caledonia. Contributions to Mineralogy and Petrology, 155, 181-198. doi:10.1007/s00410-007-0236-2

Spandler, C., Pettke, T. \& Rubatto, D., 2011. Internal and external fluid sources for eclogite-facies veins in the Monviso meta-ophiolite, Western Alps: implications for fluid flow in subduction zones. Journal of Petrology, 52, 1207-1236. doi:10.1093/petrology/egr025

Speranza, F., Villa, I.M., Sagnotti, L. et al., 2002. Age of the Corsica-Sardinia rotation and Liguro-Provençal Basin spreading: new paleomagnetic and $\mathrm{Ar} / \mathrm{Ar}$ evidence. Tectonophysics, 347, 231-251.

Staudigel, H., Plank, T., White, W.M. \& Schmincke, H.U., 1996. Geochemical fluxes during seafloor alteration of the upper oceanic crust: DSDP Sites 417 and 418. In: SUBCON: Subduction From Top to Bottom (eds Bebout, G.E., Scholl, D.W., Kirby, S.H. \& Platt, J.P.), AGU Geophysical Monograph, 19-38. 
van der Straaten, F., Halama, R., John, T., Schenk, V., Hauff, F. \& Andersen, N., 2012. Tracing the effects of high-pressure metasomatic fluids and seawater alteration in blueschistfacies overprinted eclogites: implications for subduction channel processes. Chemical Geology, 292-293, 69-87. doi:10.1016/j.chemgeo.2011.11.008

Syracuse, E.M., van keken, P.E. \& Abers, G.A., 2010. The global range of subduction zone thermal models. Physics of the Earth and Planetary Interiors, 183, 73-90. doi:10.1016/j.pepi. 2010.02 .004

Tribuzio, R., Messiga, B., Vannucci, R. \& Bottazzi, P., 1996. Rare earth element redistribution during high-pressurelow-temperature metamorphism in ophiolitic Fe-gabbros (Liguria, northwestern Italy): implications for light REE mobility in subduction zones. Geology, 24, 711-714.

Tsujimori, T. \& Ernst, W.G., 2014. Lawsonite blueschists and lawsonite eclogites as proxies for paleo-subduction zone processes: a review. Journal of Metamorphic Geology, doi:10. 1111 jmg. 12057

Tsujimori, T., Sisson, V.B., Liou, J.G., Harlow, D. \& Sorensen, S.S., 2006a. Very-low-temperature record of the subduction process: a review of worldwide lawsonite eclogites. Lithos, 92, 609-624. doi:10.1016/j.lithos.2006.03.054

Tsujimori, T., Sisson, V.B., Liou, J.G., Harlow, G.E. \& Sorensen, S.S., 2006b. Petrologic characterization of Guatemalan lawsonite eclogite: eclogitization of subducted oceanic crust in a cold subduction zone. Special Papers-Geological Society of America, 403, 147-168. doi:10.1130/2006.2403(09)

Ueno, T., 1999. REE-bearing sector-zoned lawsonite in the Sanbagawa pelitic schists of the eastern Kii Peninsula, central Japan. European Journal of Mineralogy, 11, 993-998.

Ulmer, P. \& Trommsdorff, V., 1995. Serpentine stability to mantle depths and subduction-related magmatism. Science, 268, 858-861. doi: $10.1126 /$ science. 268.5212 .858

Usui, T., 2006. Petrology and geochemistry of eclogite xenoliths from the Colorado Plateau: implications for the evolution of subducted oceanic crust. Journal of Petrology, 47, 929-964. doi:10.1093/petrology/egil01

Usui, T., Kobayashi, K., Nakamura, E. \& Helmstaedt, H., 2007. Trace element fractionation in deep subduction zones inferred from a lawsonite-eclogite xenolith from the Colorado Plateau. Chemical Geology, 239, 336-351. doi:10.1016/j. chemgeo.2006.08.009

Vitale Brovarone, A. \& Herwartz, D., 2013. Timing of HP metamorphism in the Schistes Lustrés of Alpine Corsica: new Lu-Hf garnet and lawsonite ages. Lithos, 172-173, 175191. doi:10.1016/j.lithos.2013.03.009

Vitale Brovarone, A., Groppo, C., Hetényi, G., Compagnoni, R. \& Malavieille, J., 2011a. Coexistence of lawsonite-bearing eclogite and blueschist: phase equilibria modelling of Alpine Corsica metabasalts and petrological evolution of subducting slabs. Journal of Metamorphic Geology, 29, 583-600. doi:10. 1111/j.1525-1314.2011.00931.x

Vitale Brovarone, A., Beltrando, M., Malavieille, J. et al., 2011b. Inherited Ocean-Continent Transition zones in deeply subducted terranes: insights from Alpine Corsica. Lithos, 124, 273-290. doi:10.1016/j.lithos.2011.02.013

Vitale Brovarone, A. \& Agard, P., 2013. True metamorphic isograds or tectonically sliced metamorphic sequence? New high-spatial resolution petrological data for the New Caledonia case-study Contributions to Mineralogy and Petrology, 166, 451-469.

Vitale Brovarone, A., Beyssac, O., Malavieille, J., Molli, G., Beltrando, M. \& Compagnoni, R., 2013. Stacking and metamorphism of continuous segments of subducted lithosphere in a high-pressure wedge: the example of Alpine Corsica (France). Earth Science Reviews, 116, 35-56. doi:10.1016/j. earscirev.2012.10.003
Vitale Brovarone, A., Picatto, M., Beyssac, O., Lagabrielle, Y. \& Castelli, D., 2014. The blueschist-eclogite transition in the Alpine chain: PT paths and the role of slow-spreading extensional structures in the evolution of HP-LT mountain belts. Tectonophysics, in press. doi: 10.1016/j.tecto.2014.01. 001 .

Wass, S., 1973. The origin and petrogenetic significance of hour-glass zoning in titaniferous clinopyroxenes. Mineralogical Magazine, 39, 133-144.

Whitney, D.L. \& Davis, P.B., 2006. Why is lawsonite eclogite so rare? Metamorphism and preservation of lawsonite eclogite, Sivrihisar, Turkey. Geology, 34, 473. doi:10.1130/ G22259.1

Zack, T.A., 2013. Cold slab-mantle interface: constraints from exceptionally well preserved lawsonite eclogites. Mineralogical Magazine, 77, 2574.

Zack, T. \& John, T., 2007. An evaluation of reactive fluid flow and trace element mobility in subducting slabs. Chemical Geology, 239, 199-216. doi:10.1016/j.chemgeo.2006.10.020

Zack, T., Kronz, A., Foley, S.F. \& Rivers, T., 2002. Trace element abundances in rutiles from eclogites and associated garnet mica schists. Chemical Geology, 184, 97-122.

Zack, T., Rivers, T., Brumm, R. \& Kronz, A., 2004. Cold subduction of oceanic crust: implications from a lawsonite eclogite from the Dominican Republic. European Journal of Mineralogy, 16, 909-916. doi:10.1127/0935-1221/2004/ 0016-0909

Zhang, J.X., Meng, F.C. \& Wan, Y.S., 2007. A cold Early Palaeozoic subduction zone in the North Qilian Mountains, NW China: petrological and U-Pb geochronological constraints. Journal of Metamorphic Geology, 25, 285-304. doi:10.1111/j.1525-1314.2006.00689.x

\section{SUPPORTING INFORMATION}

Additional Supporting Information may be found in the online version of this article at the publisher's web site:

Figure S1. BSE images and Ti X-ray map of Tirich lawsonite in sample 1COR12-6. (a) Large aggregate of lawsonite displaying complex BSE zoning. (b) Close up of (a). (c) Ti X-ray compositional map of (b). Note the absence of Ti-rich inclusions (e.g. rutile, titanite). (d) Complex zoning patterns in lawsonite. Note the alternating brighter and darker bands, and the outer rims. All BSE images were acquired at high contrast conditions.

Figure S2. Chondrite-normalized REE patterns (a, b) and PM-normalized trace element patterns (c, d) of titanite of the selected blueschist and eclogite facies samples.

Table S1. Electron microprobe analyses of phengite and chlorite of the selected samples.

Table S2. Electron microprobe analyses of lawsonite of the selected samples.

Table S3. Electron microprobe analyses of titanite of the selected samples.

Table S4. Electron microprobe analyses of clinopyroxene and amphibole of the selected samples. 